\title{
WRKY6 restricts Piriformospora indica- stimulated and phosphate-induced root development in Arabidopsis
}

\author{
Madhunita Bakshi ${ }^{1}$, Khabat Vahabi ${ }^{1}$, Samik Bhattacharya ${ }^{2}$, Irena Sherameti ${ }^{1}$, Ajit Varma ${ }^{3}$, Kai-Wun Yeh ${ }^{4}$, \\ lan Baldwin², Atul Kumar Johri ${ }^{5}$ and Ralf Oelmüller ${ }^{1 *}$
}

\begin{abstract}
Background: Arabidopsis root growth is stimulated by Piriformospora indica, phosphate limitation and inactivation of the WRKY6 transcription factor. Combinations of these factors induce unexpected alterations in root and shoot growth, root architecture and root gene expression profiles.

Results: The results demonstrate that $P$. indica promotes phosphate uptake and root development under Pi limitation in wrky6 mutant. This is associated with the stimulation of PHOSPHATE1 expression and ethylene production. Expression profiles from the roots of wrky6 seedlings identified genes involved in hormone metabolism, transport, meristem, cell and plastid proliferation, and growth regulation. 25 miRNAs were also up-regulated in these roots. We generated and discuss here a list of common genes which are regulated in growing roots and which are common to all three growth stimuli investigated in this study.

Conclusion: Since root development of wrky6 plants exposed to $P$. indica under phosphate limitation is strongly promoted, we propose that common genes which respond to all three growth stimuli are central for the control of root growth and architecture. They can be tested for optimizing root growth in model and agricultural plants.
\end{abstract}

Keywords: WRKY6, Piriformospora indica, Phosphate, Root development, Expression profiles

\section{Background}

Phosphorus (P) is an essential macronutrient for plant growth and development, making up to $0.2 \%$ of the plant's dry mass. $\mathrm{P}$ is involved in the regulation of many key metabolic pathways in all living organisms, including energy generation, nucleic acid and membrane synthesis, protein phosphorylation and redox reactions [1-3]. Plants absorb $\mathrm{P}$ from soil in the form of inorganic phosphate (Pi). Due to low availability and poor mobility $[4,5]$, the concentration of $\mathrm{Pi}$ in soil solutions is usually $\sim 10 \mu \mathrm{M}$, which is below the critical level needed for the optimal performance of crops and plants [6]. It is estimated that $\sim 5.7$ billion hectares of land are deficient in $\mathrm{P}$ which can be mitigated by the application of fertilizers. Pi fertilization can cause ecological problems

\footnotetext{
* Correspondence: b7oera@uni-jena.de

${ }^{1}$ Institute of General Botany and Plant Physiology, Friedrich-Schiller-University Jena, Dornburgerstr. 159, D-07743 Jena, Germany

Full list of author information is available at the end of the article
}

such as eutrophication or toxic algal blooms [7]. Soluble $\mathrm{Pi}$ in the soil also forms complexes with cations like calcium, magnesium, aluminum or iron, which are not readily absorbed by plants. Although plant growthpromoting rhizobacteria and fungi [e.g. arbuscular mycorrhizal (AM) fungi] enhance Pi uptake into the roots, microbes and weed also compete with plants for $\mathrm{Pi}$, or convert it into organic forms that are not available to support plant growth $[8,9]$.

To cope with Pi limitations, plants have evolved complex adaptive responses that include morphological and physiological modifications to improve Pi acquisition or remobilization via the differential expression of various Pi transporter genes [10, 11]. Remodeling of root architecture, inhibition of primary root length, increase of root hair density and length, as well as associations with AM or AM-like fungi are typical developmental responses to low $\mathrm{Pi}[2,12]$. The role of the AM symbiosis in enhancing $\mathrm{P}$ acquisition from soils is well known [13]. 
Piriformospora indica, a mycorrhiza-like fungus, enhances growth of monocots and dicots [14-16]. The fungus improves nutrition uptake from the soil to the host roots $[17,18]$ which also includes Pi transfer via fungal hyphae through the high-affinity Pi transporter PiPT localized to the external hyphae [19]. PiPT is highly homologous to the Saccharomyces cerevisiae high-affinity $\mathrm{Pi}$ transporter Pho84 and to plant Pi transporters (cf. [20]). In addition to stimulating Pi metabolism, $P$. indica also enhances the expression of genes for nitrate reductase and the starch-degrading enzyme glucan-water dikinase in Arabidopsis roots [17] suggesting a strong fungal influence on the plant primary metabolism. To what extend this is responsible for the benefits of the plants in their symbiotic interaction with $P$. indica is not clear. In addition to increasing the plant's biomass [21-23], enhanced resistance to biotic and abiotic stress [24, 25], the induction of systemic and local resistance $[26,27]$ and the stimulation of secondary metabolite accumulation [28] have been reported. This requires a highly balanced symbiosis in which the plants appear to control the degree of root colonization [29, 30].

WRKYs are important transcription factors (TFs) of the plant signaling web which regulate many responses to biotic and abiotic stimuli, but these TFs are also involved in responses to internal signals which coordinate developmental processes. They interact with DNA- and non DNA-binding proteins [31] and function as activators and repressors of gene expression, depending on their interaction partners and target genes [32, 33]. WRKY6, WRKY42 and WRKY75 are induced during Pi deprivation [34-36]. Chen et al. [34] showed that WRKY6 is involved in the response to low-Pi stress by regulating PHOSPHATE1 (PHO1) expression. Low Pi treatment reduced WRKY6 binding to the $P H O 1$ promoter, which indicates that $P H O 1$ regulation by WRKY6 is Pi-dependent and that low Pi levels prevent inhibition of PHO1 expression. The plant-specific WRKY75 is an activator of several $\mathrm{Pi}$ starvation-induced genes encoding phosphatases, Mt4/ TPS1-like proteins or high affinity Pi transporters [36]. Suppression of WRKY75 expression through RNAi silencing induces stress responses, such as anthocyanin accumulation [35].

We noticed that wrky6 seedlings and plants exposed to Pi limitation perform much better in the presence of $P$. indica when compared to the WT controls. $P$. indica also stimulated $\mathrm{Pi}$ uptake and translocation into the plant under Pi limitation, and these processes are restricted by WRKY6. The strong promotion of root development of wrky6 plants exposed to P. indica under Pi limitation motivated us to perform comparative expression profiles to identify genes, proteins, as well as metabolic and signaling pathways which optimize root development, especially under Pi limitation conditions.

\section{Results}

Root phenotype of WT and wrky6 seedlings under different $\mathrm{Pi}$ concentrations

WT and wrky6 seedlings (Fig. 1) were grown with/without $P$. indica on vertical PNM plates containing 2.5 or $0.25 \mathrm{mM}$ Pi for 3, 6 and 12 days. A growth-promoting effect of the fungus on the seedling's development became visible 3 days post incubation (dpi) and increased with decreasing $\mathrm{Pi}$ concentrations in the medium. In particular, root growth of both WT and wrky6 seedlings was promoted with decreasing $\mathrm{Pi}$ concentrations and further stimulated by the fungus (Figs. 1 and 2). Closer inspection revealed that the roots are denser and bushier in the presence of $P$. indica because the number and lengths of both lateral roots (Figs. 1 and 2a) as well as root hairs (Fig. 2b-d) were increased. Furthermore, stimulation of root growth by $P$. indica in the WT under Pi limitation was restricted by WRKY6. This is particularly striking for seedlings grown on $0.25 \mathrm{mM}$ Pi (Figs. 1 and 2 ): the growth-stimulating effect of $P$. indica is much stronger for wrky6 roots than WT roots (Fig. $2 \mathrm{~b}-\mathrm{d}$ ). Finally, consistent with the literature on root development after AM colonization [2], the primary root lengths of WT and wrky6 seedlings were shorter under Pi limitation conditions (Fig. 2e). These results suggest that WRKY6 has a strong influence on the root architecture and that wrky6 plants perform better than WT plants both in response to $P$. indica and Pi limitation.

Phenotypic differences become more obvious after long term interaction of the symbionts in expanded clay. After 14 days of co-cultivation in Petri dishes, $P$. indica-colonized or mock-treated WT and wrky6 seedlings grown on NP (2.5 mM, normal Pi) or LP (0.25 mM, low Pi) media were transferred to expanded clay. After 2 weeks, the first differences were observed in the size, shape and area of the leaves (Fig. 3a). P. indica-colonized wrky6 seedlings were bigger under the two $\mathrm{Pi}$ concentrations, compared to seedlings on vertical agar plates. Although all plants showed Pi stress symptoms when grown under LP conditions for 2 months, the wrky6 line performed better than the WT, and this was even more pronounced in the presence of $P$. indica. In particular, after 2 months, a significant increase in fresh weight (Fig. 3b, c) and shoot length (Fig. 3d) was observed for $P$. indica-treated wrky6 seedlings (grown on NP medium) compared to the untreated control and the WT. This confirms that WRKY6 restricts $P$. indicamediated growth promotion.

\section{Low Pi enhanced $P$. indica colonization in WT seedlings}

To assess the effect of $\mathrm{Pi}$ on root colonization, the fungal spores associated with Arabidopsis roots were stained with Trypan Blue. Fig. 4a demonstrates that the number 


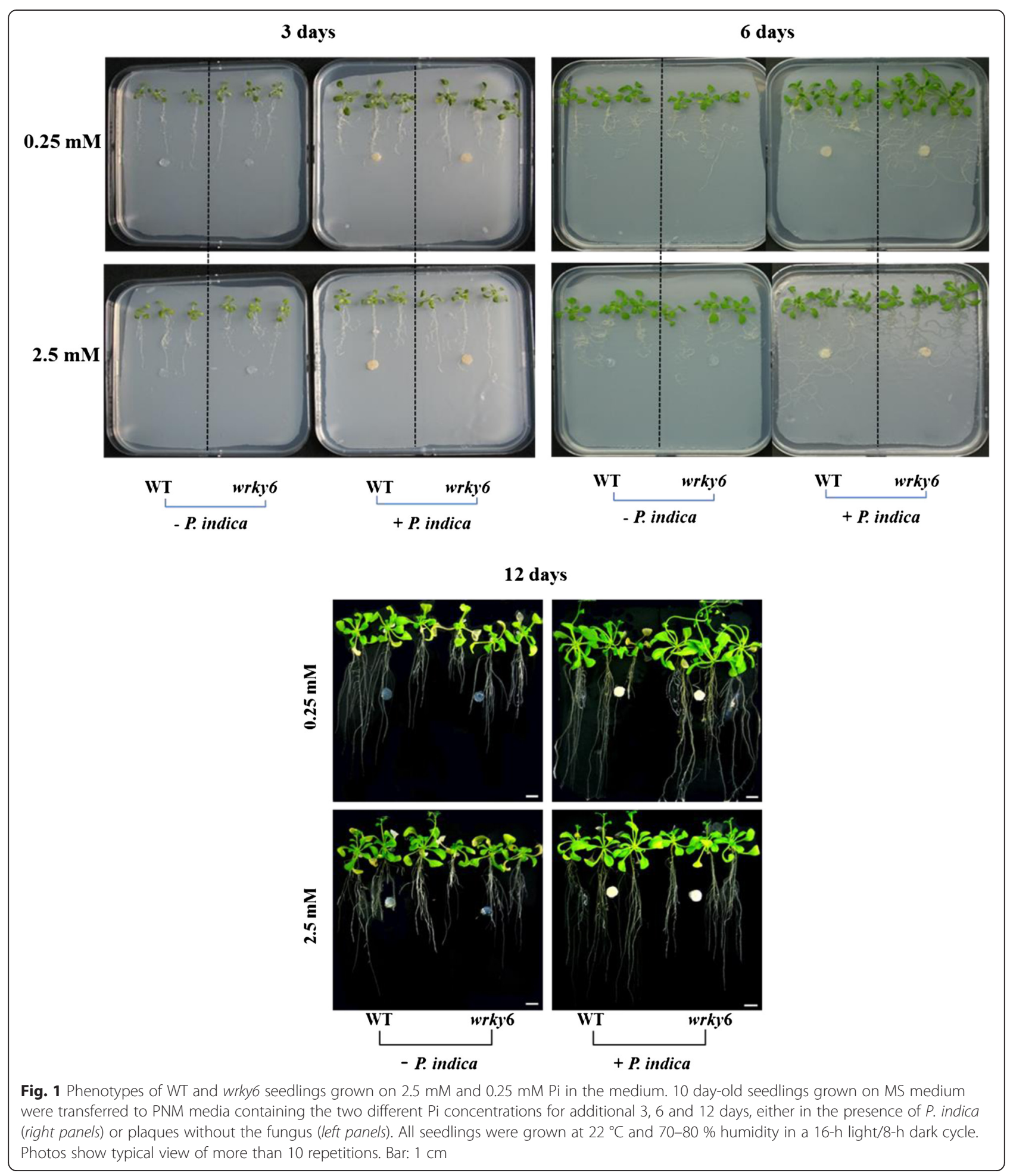

of spores associated with WT roots was higher under LP than NP conditions, and this was not observed for wrky6 seedlings. The colonization by $P$. indica was also confirmed by quantitative RT-PCR with the $P$. indica- specific marker gene $E F-H$, relative to the plant GAPDH gene (Fig. 4b). These results highlight the strong effect of root colonization for WT seedlings grown under LP conditions (cf. Discussion). 


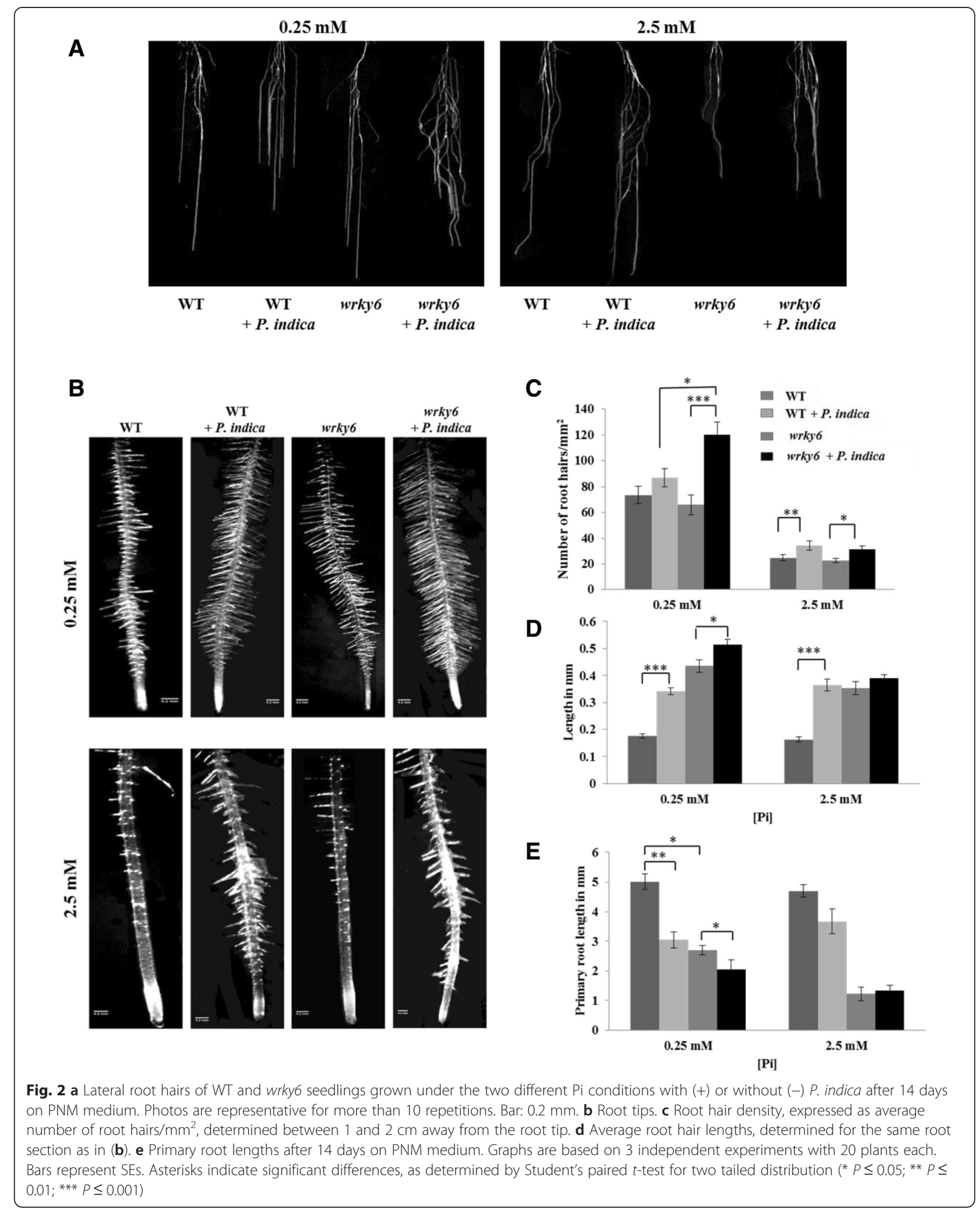




\section{$P$. indica stimulates ethylene (ET) production in LP-grown wrky6 seedlings}

ET plays an important role in primary root growth and root hair formation in seedlings growing under Pi limitation [37], and has a strong influence on hyphal growth, branching and root colonization [38]. As shown in Fig. 5, ET released from WT seedlings was $>2$-fold lower under LP than under NP conditions. The ET production of uncolonized wrky6 seedlings was comparable under the two Pi concentrations. In all instances, $P$. indica stimulated ET production, but significant stimulation was only observed for wrky6 seedlings. LP-, but not NP-grown mutant seedlings produced $\sim 2$-times more ET than the WT, irrespective of whether the seedlings were exposed to the fungus or not. The higher ET production of wrky6 seedlings under LP conditions compared to the WT might contribute to the change in the root architecture and the lower root colonization of the mutant (37-38, cf. Discussion).

\section{P. indica promotes PHOSPHATE1 (PHO1) expression under Pi limitation}

PHO1 is a high affinity Pi transporter expressed predominantly in the roots, and the gene is up-regulated under low Pi conditions [39]. We observed a 23 -fold stimulation of PHO1 expression by P. indica in wrky6 roots under Pi limitation, but not under NP conditions (Fig. 6). This confirms previous observations that WRKY6 acts as a repressor of PHO1 expression under NP conditions. The strong effect of $P$. indica on root development is reflected by the up-regulation of $\mathrm{PHO} 1$ under Pi limitation.

\section{${ }^{32} \mathrm{P}$ uptake and inorganic $\mathrm{Pi}$ content}

Figure 7a shows that the radioactivity in all parts of the $P$. indica-exposed seedlings is higher than in non-colonized plants, irrespective of whether they were grown under NP or LP conditions, and we observed a $\sim 2$-fold stimulation of ${ }^{32} \mathrm{P}$ uptake in the presence of the fungus in both WT and wrky6 seedlings (Fig. 7b). The comparable stimulation of Pi uptake by $P$. indica in the two genotypes demonstrates that the strong fungus-induced growth alteration in the wrky6 mutant is not exclusively caused by a more efficient Pi uptake. In addition, the total amount of $\mathrm{Pi}$ in the seedlings cannot explain the fungusinduced phenotypic differences between wrky6 and WT (Fig. 7c). As expected, the total Pi content in the seedlings is dependent on the $\mathrm{Pi}$ concentration in the medium, and seedlings grown under LP conditions contain less Pi than those grown on NP conditions. However, for a given $\mathrm{Pi}$ concentration in the medium, we did not observe significant differences of the total $\mathrm{Pi}$ content in the seedlings of the two genotypes or the presence or absence of the fungus (Fig. 7c). Thus, also the comparable amount of $\mathrm{Pi}$ in colonized and uncolonized WT and wrky6 seedlings cannot explain the differences in the root architecture observed among the seedlings grown under LP conditions (cf. Discussion).

\section{Pi-regulated genes in $P$. indica-colonized wrky 6 roots}

The strongest stimulation of root growth was observed when NP-grown $P$. indica-colonized wrky6 seedlings were compared to those grown on LP (Figs. 1 and 2). Therefore, we first identified genes which were regulated by $P$. indica only in wrky6 roots (and not in the WT) and only under Pi limitation (Additional file 1: Table S1). Mapman categorization revealed that 9 auxin-related genes code for small auxin up RNAs (SAURs). Others code for an auxin efflux regulator, auxin response factors (e.g. ARF12), auxin-regulated TFs (e.g. LEAF COTYLEDON2) or are auxin targets (e.g. expansins, cell wall biosynthesis enzymes). Down-regulation of IAA34, encoding a repressor of ARFs [40, 41] further supports that the auxin metabolism is activated. Two genes ([NINE-cisEPOXYCAROTENOID DIOXYGENASE4 [42] and HVA22 [43]) are involved in ABA functions. GA REQUIRING1, GA 20-OXIDASE3 and GA 2-OXIDASE7 are key players in gibberellin (GA) biosynthesis [44, 45].

Numerous transport processes are stimulated, as shown by the regulation of genes for $\mathrm{p}$ - and $\mathrm{v}$-ATPases, carbohydrate, amino acid, lipid, nucleotide, Pi, nitrate and metal transporters, $\mathrm{ABC}$ and metabolite transporters, as well as aquaporins.

Re-organisation of the root architecture is also reflected by the stimulation of genes for the primary (e.g. glucose) and secondary (e.g. stress) metabolisms, developmental processes, cell organization, cell cycle, vesicle transport, growth regulators and early signaling compounds. Among the latter group are compounds (such as the $\mathrm{Ca}^{2+}$-binding CALMODULIN-LIKE37 and receptor kinases) which have not yet been analyzed in roots. This highlights that many of the $P$. indica-induced responses to LP stress in the WT are restricted by WRKY6.

Interestingly, 25 miRNAs, 10 with known and 15 with unknown functions, are regulated in the bigger roots. miR156G, miR169F, $m i R 395 B$ and $m i R 399 C$ respond to Pi starvation $[46,47]$. miR394B targets the mRNA for an F-box protein of the SKP1-Cullin/CDC53-F-box complex, and is involved in auxin responses [48]. miR169F targets the mRNA for the subunit A of the NF-Y TF complex thereby controlling primary and lateral root initiation [49]. Furthermore, ALKENYL HYDROXALKYL PRODUCING2 is involved in glucosinolate biosynthesis and predicted to be targeted by miR826 and miR5090, and both miRNAs are induced in response to Pi starvation [50]. All these miRNAs are regulated by $P$. indica in LP-exposed wrky6, but not WT roots. This highlights the importance of this TF on the restriction of root development under Pi limitation. 


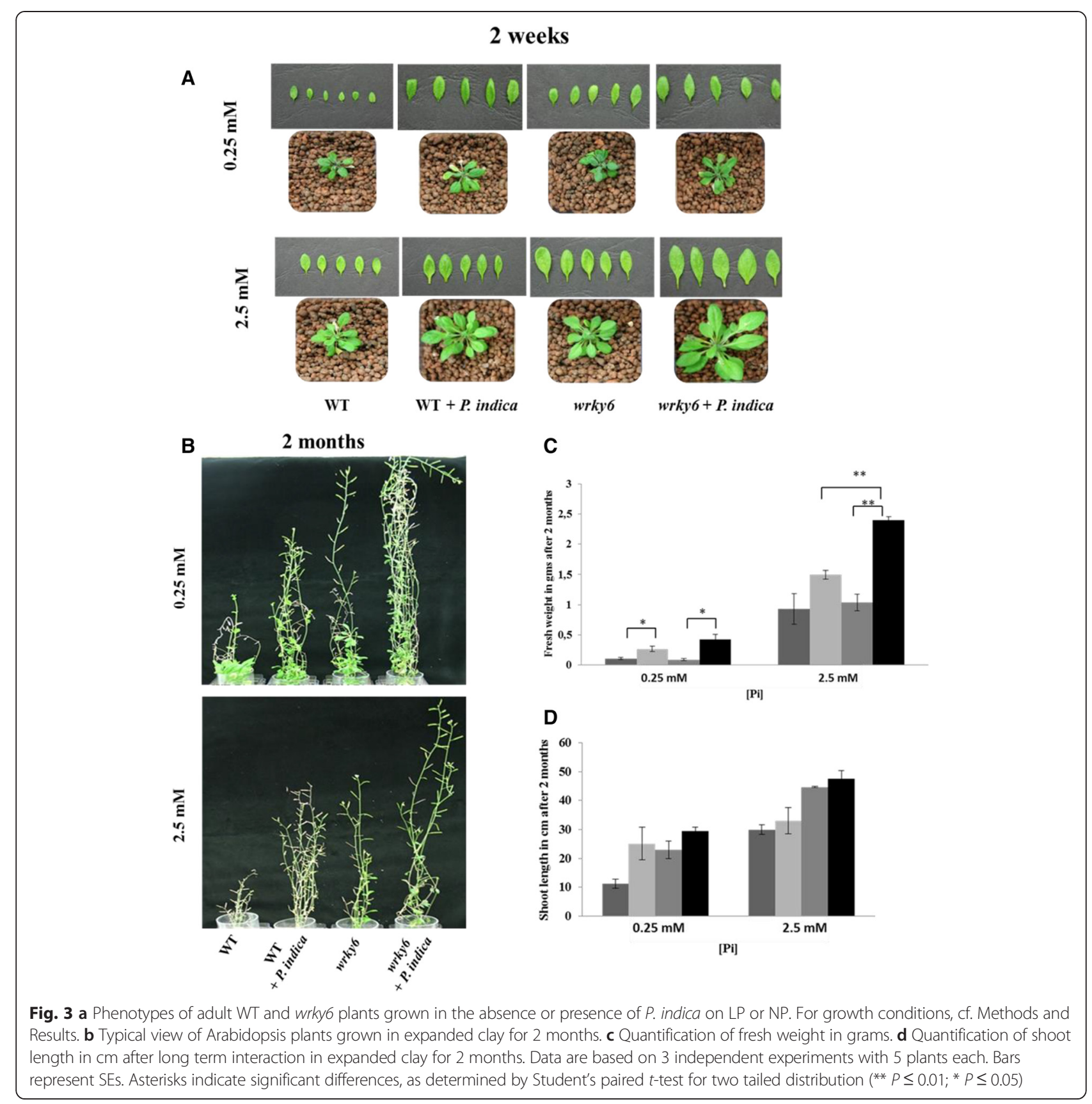

A functional categorization of genes based on a) involvement in" biological process", b) involvement in "molecular function", c) involvement in "cellular component" and regulated more than 2-fold in response to LP based on A. thaliana Gene Ontology (TAIR's GO annotations) is given in (Fig. 8).

\section{Proposed list of general genes involved in root growth promotion}

The Venn-diagrams (Fig. 9) generated by the MAPMAN software identified genes, which were regulated by LP (but not $P$. indica or WRKY6), by $P$. indica (but not LP or WRKY6), and by WRKY6 (but not $P$. indica or LP). The common genes among these three datasets are not specific for one of the three stimuli and should therefore represent more general genes involved in the promotion of root growth and development (Fig. 9). Those genes were then arranged according to their average fold regulation in all datasets (Table 1, 4-fold; Additional file 2: Table S2). The higher the genes are ranked in the list, the more important appears to be their requirement during root growth.

91 genes are regulated more than 4-fold $\left(\log _{2}>2\right)$ in all 3 datasets and only 2 of them are down-regulated 

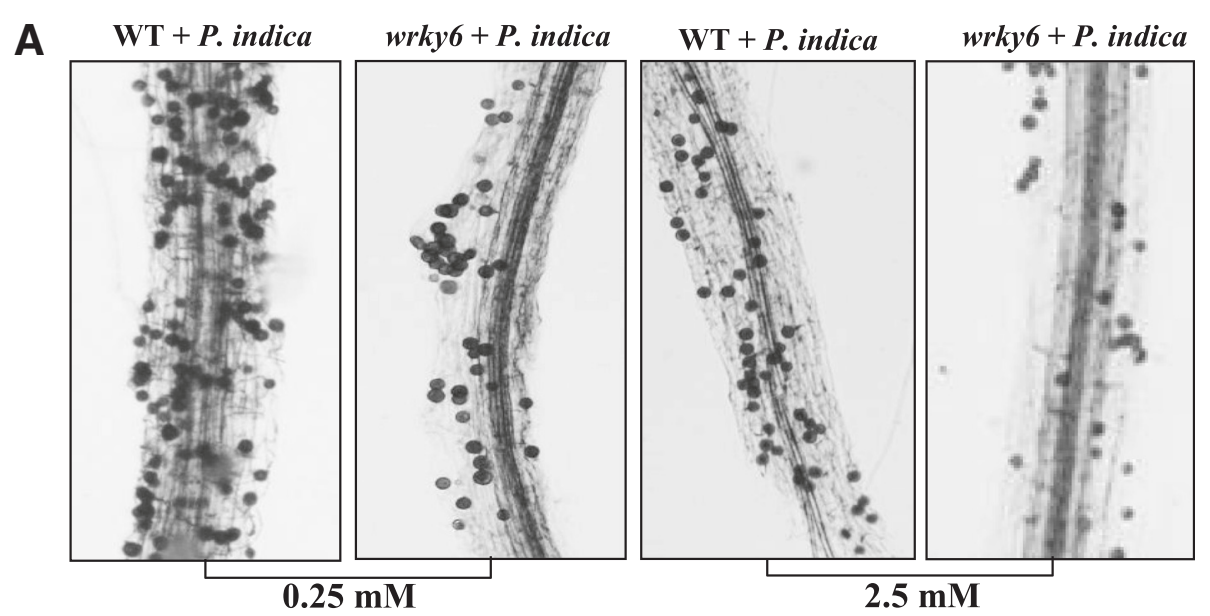

B

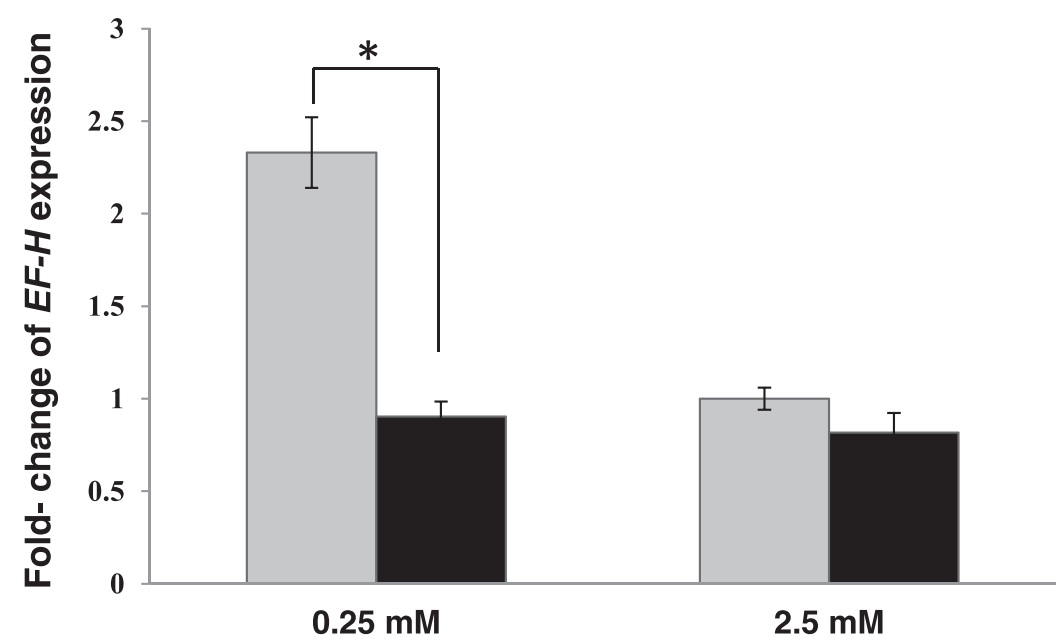

[Pi]

Fig. 4 a Colonization of WT and wrky6 Arabidopsis roots by $P$. indica after co-cultivation under $0.25 \mathrm{mM}$ and $2.5 \mathrm{mM}$ Pi concentrations in the media. The fungal material was stained with Trypan Blue. Photos are representative for more than 10 repetitions. b Quantification of the degree of root colonization by quantitative RT-PCR. The amount of fungal material (determined as fungal DNA with $P$. indica-specific primers) is expressed relative to the plant GAPDH DNA (determined with GAPDH-specific primers). Graphs are based on 3 independent experiments with 20 plants each. Bars represent SEs. Asterisk indicates significant difference, as determined by Student's paired $t$-test for two tailed distribution $(* P \leq 0.05)$

(Table 1). For 28 of them, we could not find sufficient information to predict a function of their products. In addition, for 59 gene products, we did not find functional analysis data or predictions for roots.

It appears that root growth is associated with water shortage (At1g26850) and a high demand for sugar (At5g62850). SWEET5 appears to play a major role in providing photoassimilates via the phloem to the roots and for the fungus, as its message is the only one of the SWEET sucrose efflux transporter gene family [51] in the list. The auxin/cytokinin ratio is important for root/ shoot ratios. Only 3 genes involved in the auxin and cytokinin metabolism are in the list: SAUR2 participating in cell expansion, an auxin-inducible uncharacterized leucine-rich repeat protein (At1g24650) [52] and the predicted TF At5g27140 which responds to cytokinin through the histidine-to-aspartate photorelay circuit [53]. Interestingly, no other hormone-related genes were highly ranked among the common genes.

Among the proteins known to be involved in cell wall extension such as xyloglucan endotransglucosylasehydrolases, expansins, polygalacturonases or peroxidases, the uncharacterized pectin methylesterases At1g69940 and At1g11590 appear to be important. Cell growth requires an increase in exocytosis, which is reflected by the highly ranked SNF7 gene in the list. SNF7 is involved in internal vesicle formation of the prevascular compartment [54]. Specific members of gene families (such as At1g07725 of the EXOCYST70 family) participate in the stimulation of the export in growing cells. The 


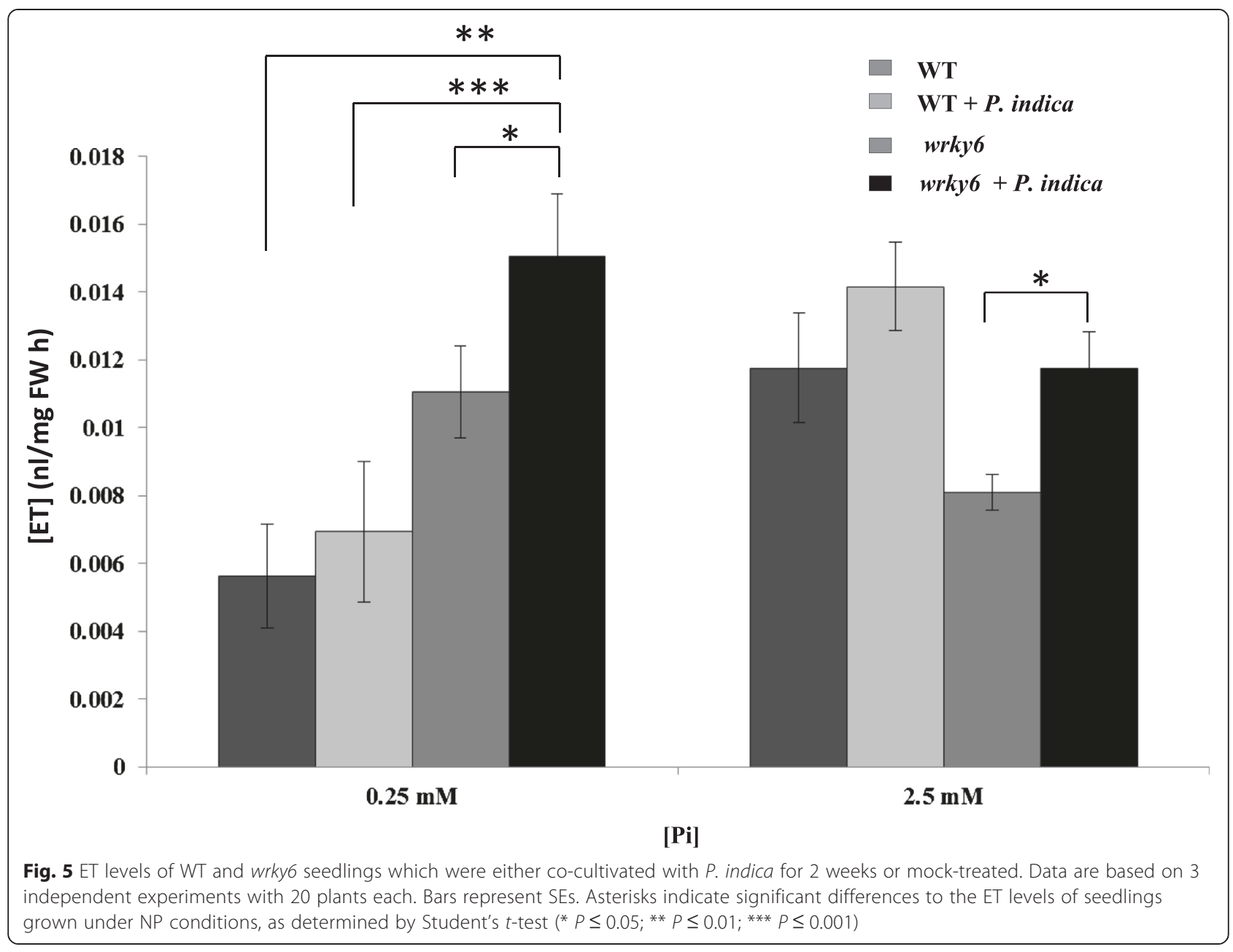

increased demand for lipids is reflected by genes involved in lipid metabolism (At4g33355; At1g21540). Control of the redox potential (At3g45880, At2g33270) and specific plastid functions, such as the import into the organelle (At5g07930), appear to be important. Rapid responses to developmental changes have been associated with posttranscriptional processes mediated by PUMILIO proteins (At5g56510) [55]. Closer inspection of the genes regulated $>4$-fold using the TAIR and NCBI databases revealed that additional not well characterized proteins are potentially associated with root or cell growth, but this requires further studies. In addition, extension of the list of genes by reducing the threshold level to 2-fold regulation in all three conditions (Additional file 2: Table S2, 2-fold) uncovered additional $\sim 100$ proteins with predicted growth related functions (TAIR homepage), such as REPRODUCTIVE MERISTEM1, GROWTH REGULATING FACTOR4, EXPANSIN23, the RmIC-like cupin protein At1g03890, HISTONE ACETYLASE18, the $\mathrm{Ca}^{2+}$-dependent PROTEIN KINASE14, LIFEGUARD1 and SYNAPTOTAGMIN2, to mention a few. Finally, the function of the strongly down-regulated HVA22J-like PROTEINJ needs to be analyzed.

In summary, very limited information is available for the majority of the genes which respond to the three root growth stimulators analyzed in this study.

\section{Discussion}

Low Pi is a major stress for plants. Therefore, plants have evolved complex mechanisms for acquisition, remobilization and recycling of Pi to maintain the P homeostasis in a cell. Spatio-temporal molecular, physiological and biochemical Pi deficiency responses are the consequence of local and systemic sensing and the activation of signaling pathways. They stimulate $\mathrm{Pi}$ metabolism, but also initiate developmental reprogramming leading to changes in the root system architecture [56]. Among the 74 WRKY members in Arabidopsis, WRKY6, -42 and -75 are involved in LP stress $[34,35]$. For the studies performed here, we observed a strong positive effect on plant performance when the WRKY6 gene was inactivated. Therefore this WRKY protein was investigated in more details. Furthermore, $P$. indica helps plants to 


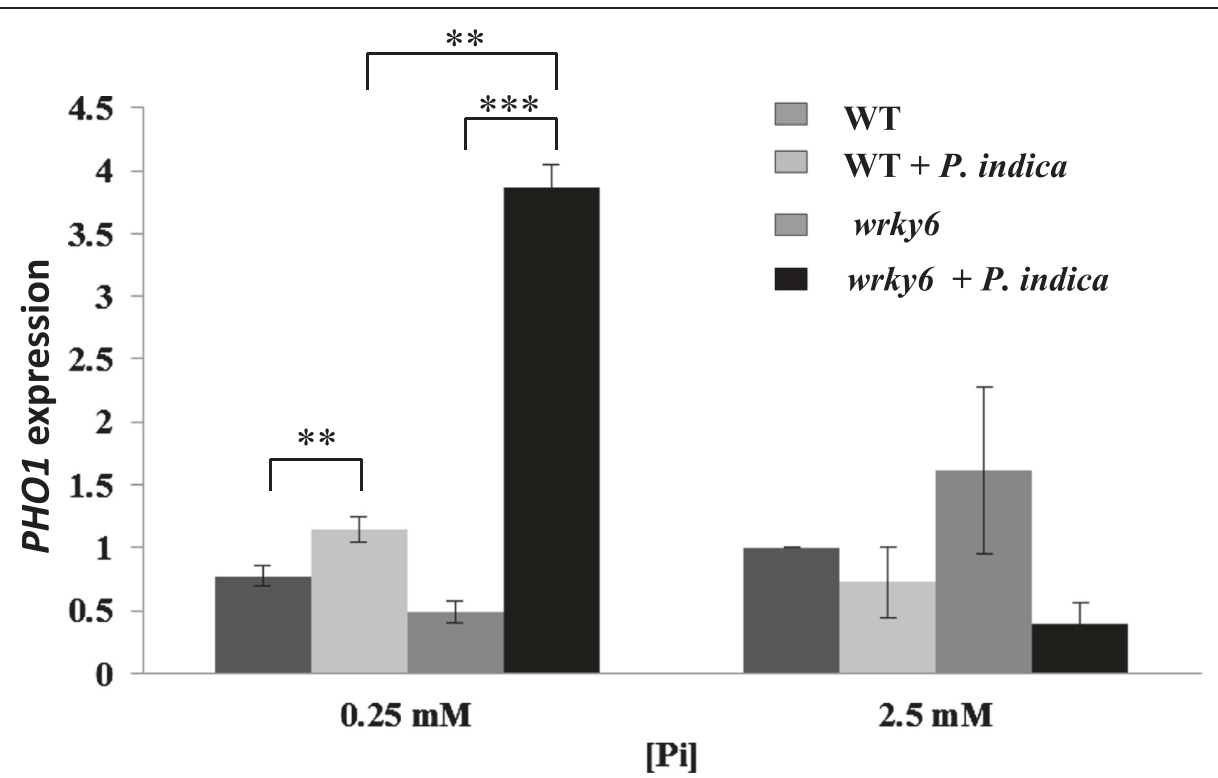

Fig. 6 PHO1 expression after 3 days of co-cultivation or mock-treatment of the two symbionts under the two different Pi concentrations. Data are based on 3 independent experiments with 15 plants each. Bars represent SEs. Asterisks indicate significant differences, as determined by Student's paired $t$-test for two tailed distribution (** $P \leq 0.01 ;{ }^{* *} P \leq 0.001$ )

adapt to various stress conditions and supplies them with nutrients including Pi which leads to root growth promotion [14, 16]. Interestingly, Müller et al. [57] performed microarray analyses for Pi-starved Arabidopsis leaves. 73 of their genes are also regulated in our microarrays with WT roots. The number is reduced to 37 when the seedlings are grown in the presence of $P$. indica (compare Müller et al. [57]). This confirms that the fungus reduces the Pi stress response in Arabidopsis roots. Here, we demonstrate that the three unrelated factors "presence of $P$. indica", "limitation of $\mathrm{Pi}$ " and "absence of WRKY6" strongly influence plant growth and in particular the root architecture. The stimulating effects of the fungus and Pi limitation are restricted by WRKY6. Under NP conditions, the difference in the response to $P$. indica among the two genotypes is smaller than under LP conditions (Figs. 1 and 2). These effects are not only visible at the seedling's level but persist after shifting the seedlings to expanded clay (Fig. 3). The root hair density and length are strongly promoted by $P$. indica in the wrky6 mutant in comparison to the WT grown under LP conditions (Fig. $2 \mathrm{~b}-\mathrm{d}$ ), while the length of the primary roots is reduced (Fig. 2e). Chen et al. [34] also observed phenotype differences between WT and wrky6 plants under LP conditions, but the root architecture was not analyzed in details. Robatzek and Somssich [58] did not observe differences between wrky6 and WT, but their growth conditions were quite different from ours and those of Chen et al. [34]. Similar alterations in the root architecture in response to LP occur after AM colonization [59-61], and in P. indica- colonized Chinese cabbage seedlings [16, 62, 63]. Chinese cabbage showed a stronger response to $P$. indica than Arabidopsis. The interaction results in a bushy root phenotype, comparable to our observations with LPgrown wrky6 seedlings (Fig. 2).

$\mathrm{PHO} 1$ participates in the transfer of Pi from root epidermal and cortical cells to the xylem [39]. This may explain the better performance of the aerial parts of the $P$. indica-colonized mutant under $\mathrm{Pi}$ limitation. Low $\mathrm{Pi}$ treatment reduced WRKY6 binding to the PHO1 promoter [34]. Furthermore, inactivation of WRKY6 stimulated PHO1 expression by $P$. indica under LP, but not NP conditions (Fig. 6). This suggests that a WRKY6independent regulatory mechanism exists that stimulates PHO1 expression under LP by signals from $P$. indica. Mycorrhizal symbiosis also enhances the expression of various Pi transporter genes like OsPT11 in rice [64] and MtPT4 in Medicago trunculata [65]. P. indica also stimulates the expression of other $\mathrm{Pi}$ transporter genes including Pht1;5 in LP-grown wrky6 seedlings. The Pht1;5 promoter contains W-boxes [34, 35] which are putative binding sites for WRKY TFs. Since Pht1;5 is not upregulated in WT seedlings under these conditions, WRKY6 might function as a transcriptional repressor for this gene (data not shown). Furthermore, consistent with previous observations $[18,19,66]$, we found an increase in $\mathrm{Pi}$ uptake in the presence of $P$. indica under low Pi conditions, however there is no difference between WT and wrky6 seedlings (Fig. 7). Stimulation of Pi uptake by $P$. indica might establish local Pi gradients which could result in altered local Pi stress responses, 


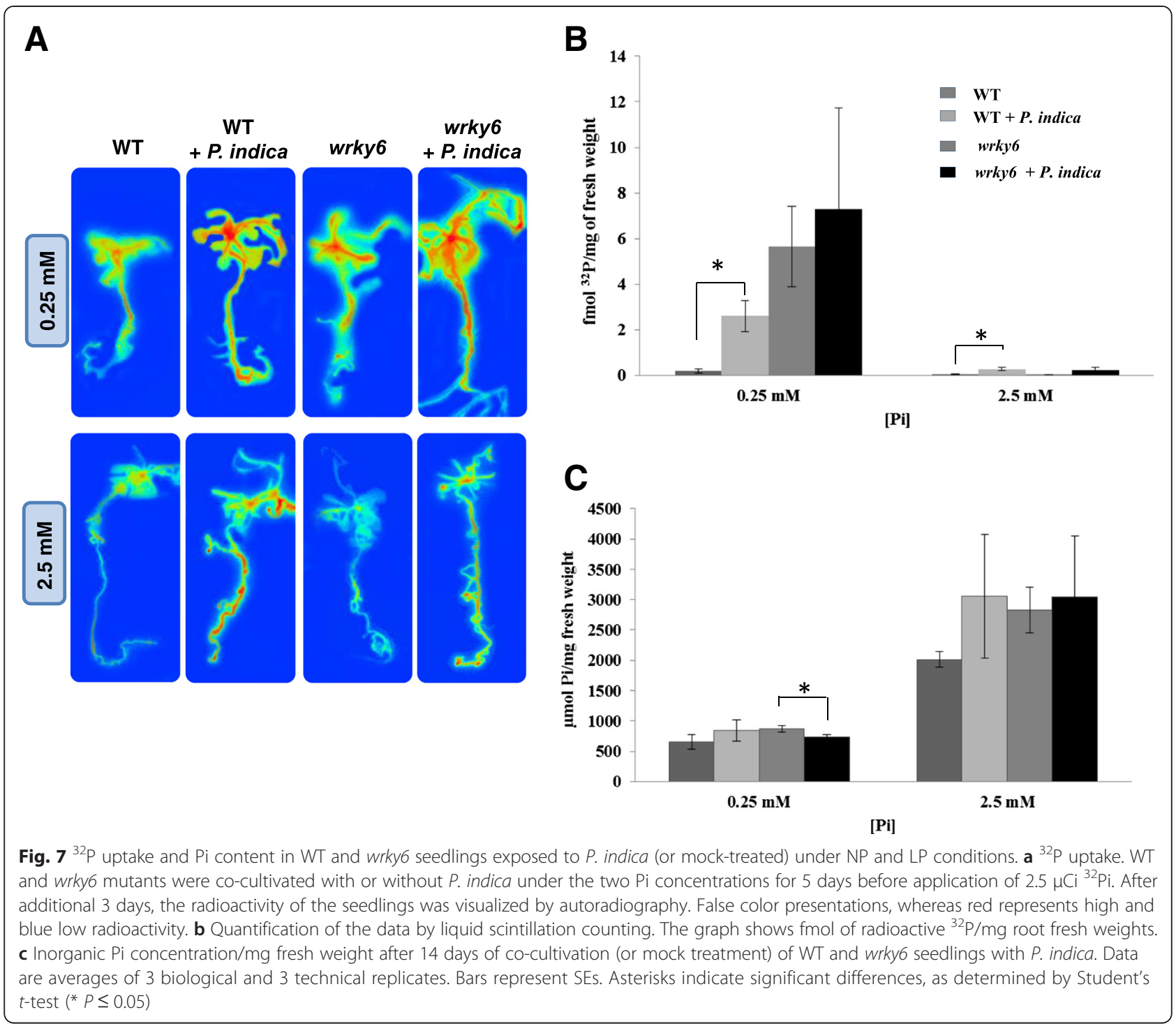

and a reprogramming of root developmental programs. These programs are initiated by Pi limitation and further promoted by $P$. indica and the absence of WRKY6. Mycorrhizal fungi association is a well-known strategy of plants for enhancing Pi uptake [61, 67]. In spite of a more efficient Pi uptake in the presence of $P$. indica, the overall Pi content in colonized or uncolonized WT and wrky6 seedlings is not different, although seedlings grown under $\mathrm{Pi}$ limitation conditions contain less $\mathrm{Pi}$ than those grown under NP conditions (Fig. 7). This again is consistent with the idea that limitations in the $\mathrm{Pi}$ availability induce growth and alterations in the root architecture. $P$. indica either reduces the Pi limitations or interferes with the signaling events activating the $\mathrm{Pi}$ stress response. Plants grown under Pi limitation use their own Pi reservoir to maintain Pi homeostasis within cells [68] and simultaneously stimulate the Pi uptake machinery $[69,70]$. The RmIC-like cupins protein which is up-regulated at the mRNA level during root growth (Additional file 1: Table S1, Additional file 2: Table S2) has been proposed to have nutrient reservoir activity and is a candidate for controlling Pi availability.

In LP conditions, ET is an important factor for inhibition of primary root growth and promotion of lateral root elongation [2, 37]. Plant-derived ET also stimulates spore germination and hyphal growth of vesicular AM $[38,71]$. As shown in Fig. 5, colonized and un-colonized mutant seedlings produced $\sim 2$-times more ET than WT seedlings. Since WT plants with less ET production are more colonized than wrky6 plants irrespective of the $\mathrm{Pi}$ level in the root environment (Fig. 4), ET may restrict root colonization. Thus, this hormone might be important to balance growth of the microbe, the resulting benefits for the host, and the degree of defense gene 


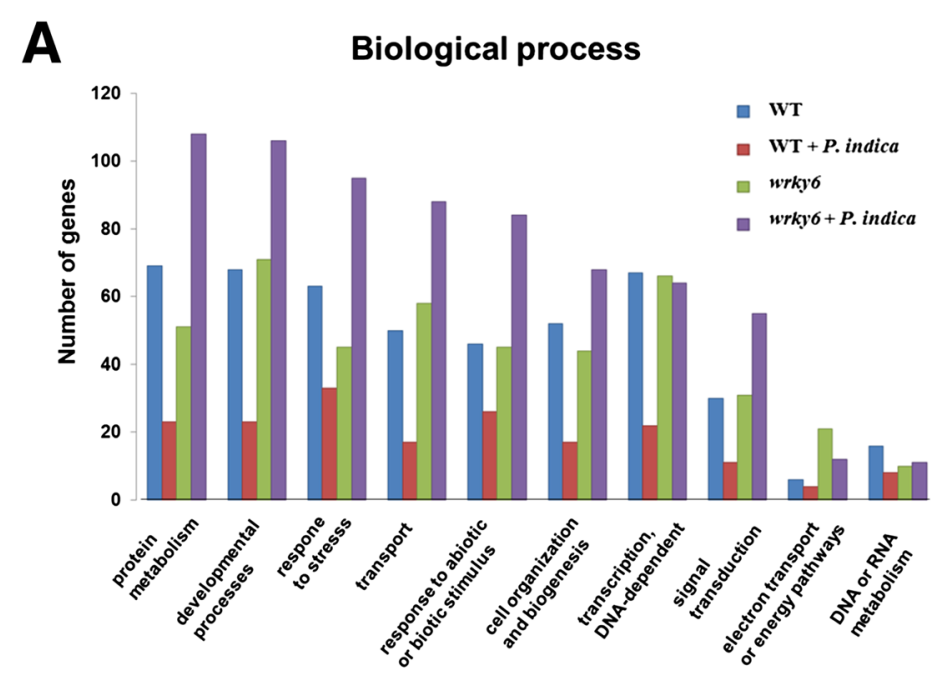

B

Molecular functions
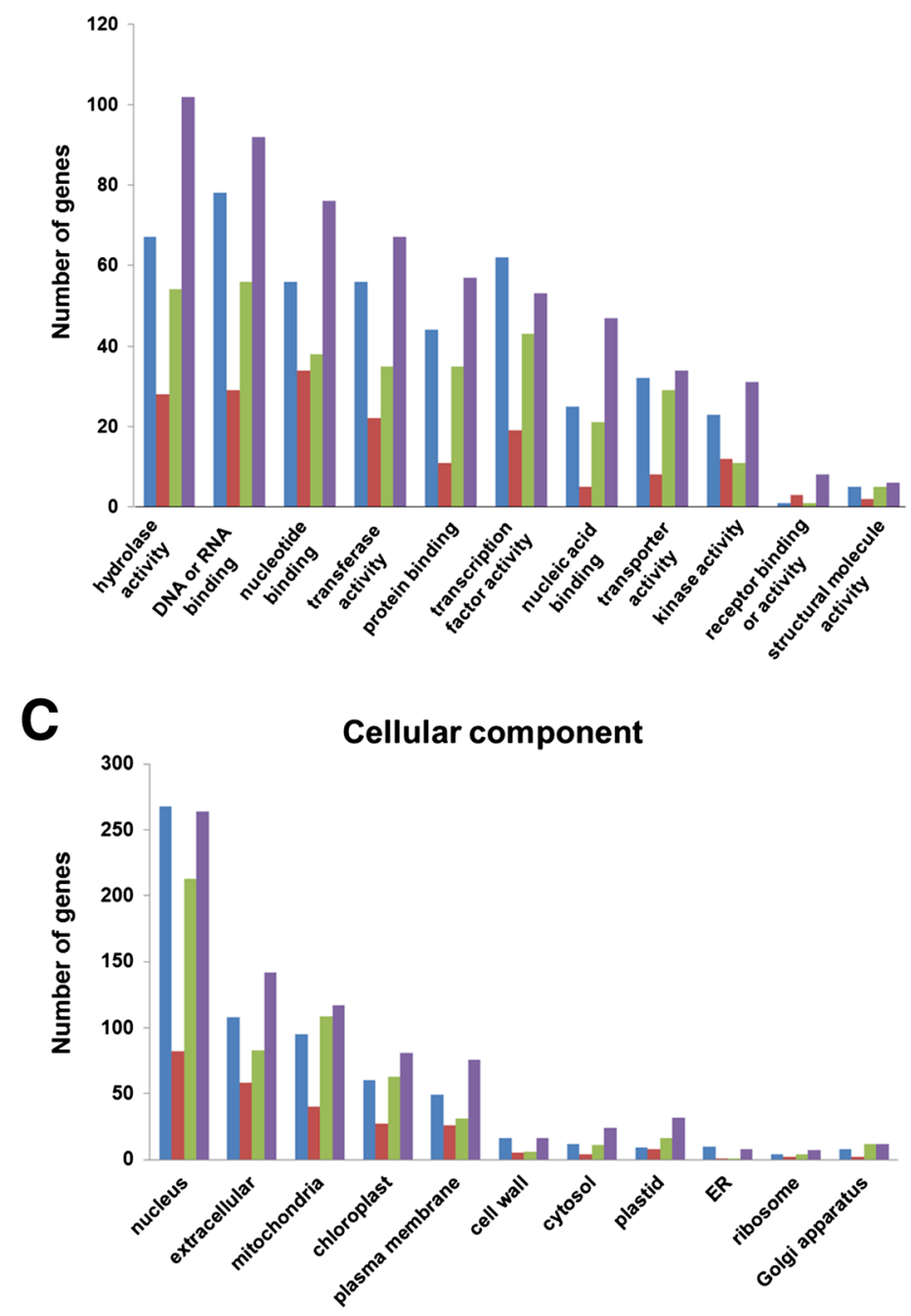

Fig. 8 Functional categorization of genes which are regulated more than 2-fold in response to LP based on A. thaliana Gene Ontology (TAIR's GO annotations). a Genes involved in "biological process". b Genes involved in "molecular function". c Genes involved in "cellular component" 


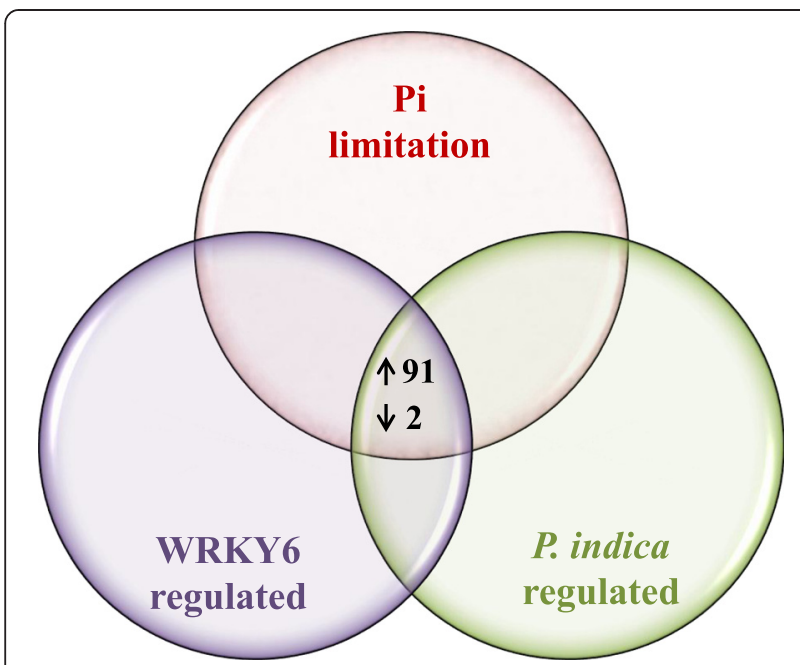

Fig. 9 Common up- and down-regulated genes ( $>4$ fold) in Arabidopsis roots regulated either by Pi limitation, WRKY6 or $P$. indica (Venn diagram). For experimental details, cf. Methods and Results

activation of the host against the invader. Under our growth conditions, the higher ET level in wrky6 plants may stimulate lateral root development, spore germination and hyphal growth, which is consistent with the better performance of the wrky6 roots. The important role of ET and ET signaling components for mutualistic interaction of Sebacinales with various plant species has also been demonstrated by Khatabi and Schäfer [30], Camehl et al. [72] and Barazani et al. [23]. Taken together, WRKY6 is a crucial player in controlling root development in response to $P$. indica and Pi limitation.

\section{Microarray analyses}

Since the strongest growth-promoting effect and change in the root morphology were observed for $P$. indicacolonized wrky6 seedlings in LP, we used the roots of these seedlings to identify genes which cause this phenotype (Fig. 2). Many genes with known growthrelated functions were identified (Additional file 1: Table S1, Additional file 2: Table S2). This includes genes for proteins involved in the primary metabolism (e.g. for the generation of energy-rich components), cell wall metabolism (e.g. methyl-pectinerases, expansins), hormone biosynthesis and signaling (proteins involved in auxin-, gibberellin-, ET-, jasmonic acid-, brassinosteroid and strigolactone-associated processes), or secondary metabolism (e.g. for stress or defense compounds or antioxidants).

Various well-characterized genes for developmental processes were specifically up-regulated in these roots, such as genes for the GROWTH REGULATOR4 (At3g52910), for cell regulation, transporters of ions, peptides, oligonucleotides or other small molecules. Also previously described proteins involved in the $P$. indical Arabidopsis interaction were detected: e.g. components involved in protein sorting (cf. [73]), cytoskeleton rearrangement (cf. [21]) and MATH domain-containing proteins [74]. However, the majority of the genes are not or little characterized or not studied in roots yet.

WRKY6 restricts auxin-mediated growth responses in the WT (cf. also [75]). Among the identified genes is SAUR21 which contributes to cell expansion and basipetal auxin transport [76]. SAUR1, $-6,-7,-17,-27,-49,-64$ and -65 participate in various aspects of root development (TAIR homepage). The AUXIN-RESPONSE FACTOR (ARF) 12 functions in Pi homeostasis in rice [77] and is essential for root growth through maintaining a correct polarization of the auxin transport machinery in Arabidopsis [78]. Expansin 10, B1, B3 and A5 participate in cell expansion and root epidermis cell differentiation $[79,80]$. Only four genes for enzymes involved in cell wall biosynthesis are in the list: cellulose synthase-like D4 involved in root cell tip growth [81], cellulose synthase 10 and cellulose synthase-like D6 and -G3. Yang et al. [82] demonstrated that jasmonate prioritizes defense over growth by interfering with the GA signaling cascade. Consistent with this idea we observe up-regulation of 3 key enzyme genes for GA biosynthesis, while relatively few genes involved in defense responses are up-regulated and many of them are even down-regulated in $P$. indica-colonized wrky6 seedlings in LP (Additional file 1: Table S1).

The role of miRNAs in plant-microbe symbiosis with nitrogen-fixing rhizobia [83], AM fungi [16, 84, 85] and plants grown under biotic and abiotic stress $[86,87]$ is well documented. Several mi/siRNAs target members of the ARFs family are involved in auxin homeostasis and signaling supposing their participation in crucial stages of root development [88]. Ye et al. [16] reported $P$. indica-mediated induction of several miRNAs which ultimately leads to growth promotion and vigorous root development in Oncidium hybrid orchid. Consistent with a huge number of publications, it appears that control of root development involves miRNAs with various functions and targets ( $\mathrm{Li}$ and Zhang [89]). It is particularly interesting to understand the function of the newly identified miRNAs regulated during root growth promotion. Taken together, the combination of these genes appear to be crucial for reprogramming root development under $\mathrm{Pi}$ limitation and the presence of $P$. indica in wrky6.

\section{General genes}

Genes which are regulated by all three quite diverse growth stimuli should code for common components involved in root growth. Genes with higher priority for growth should show a stronger regulation in response to the three stimuli than those which are less required. 
Table 1 Genes which are regulated more than 4-fold (log2 value $\geq 2$ ) in response to Pi limitation, P. indica and mutation of WRKY6

\begin{tabular}{|c|c|c|c|c|c|}
\hline Mapman BinCode & Gene ID & Gene Description & Pi limitation & P. indica & wrky6 \\
\hline 20.2 .3 & At1g26850 & dehydration-responsive family protein & 6.0 & 7.1 & 6.9 \\
\hline 35.1 .26 & At4g11540 & DC1 domain-containing protein involved in intracellular signaling & 5.9 & 7.0 & 6.9 \\
\hline 35.2 & At4g08593 & unknown protein & 6.4 & 6.3 & 6.9 \\
\hline 27.3.72 & At5g67480 & BTB AND TAZ DOMAIN PROTEIN 4 & 5.8 & 6.9 & 6.8 \\
\hline 35.2 & At3g09975 & unknown protein & 6.6 & 6.7 & 5.9 \\
\hline 35.2 & At5g46220 & unknown protein & 5.9 & 5.8 & 5.6 \\
\hline 27.3.71 & At4g29160 & SNF7 & 5.6 & 5.9 & 5.8 \\
\hline 26.21 & At4g33355 & lipid binding protein & 5.7 & 5.1 & 5.8 \\
\hline 21.4 & At4g08550 & electron carrier/ protein disulfide oxidoreductase & 5.5 & 5.4 & 5.1 \\
\hline 35.2 & At3g45880 & 2-oxoglutarate and $\mathrm{Fe}^{2+}$-dependent oxygenase & 5.8 & 5.8 & 4.2 \\
\hline 30.3 & At1g32250 & putative calmodulin & 5.4 & 5.3 & 5.1 \\
\hline 29.5 & At5g09640 & SCPL19 (serine-type carboxypeptidase) & 4.8 & 5.6 & 4.8 \\
\hline 35.1 & At2g01790 & meprin and TRAF homology domain-containing protein & 5.1 & 5.1 & 5.0 \\
\hline 27.3.41 & At3g46770 & transcription factor of the B3 family & 2.2 & 6.4 & 6.4 \\
\hline 27.3.11 & At1g51220 & WIP5 (zinc finger protein) & 4.8 & 5.3 & 4.7 \\
\hline 35.2 & At2g18200 & unknown protein & 5.1 & 4.9 & 4.8 \\
\hline 27.3.24 & At1g65360 & AGL23 (AGAMOUS-LIKE 23) & 4.9 & 5.1 & 4.5 \\
\hline 29.5.11.4.3.2 & At5g44980 & F-box family protein & 6.6 & 3.5 & 4.4 \\
\hline 27.3.67 & At5g27140 & putative SAR DNA-binding protein & 3.0 & 5.9 & 5.4 \\
\hline 27.2 & At1g30455 & transcription factor & 4.6 & 5.1 & 4.5 \\
\hline 33.99 & At5g62850 & SWEET5 & 4.7 & 4.7 & 4.7 \\
\hline 35.2 & At4g27930 & unknown protein & 4.5 & 4.7 & 4.7 \\
\hline 17.2 .3 & At4g34780 & auxin-responsive protein & 4.8 & 4.0 & 4.9 \\
\hline 27.4 & At5g53720 & RNA recognition motif -containing protein & 4.4 & 4.5 & 4.5 \\
\hline 29.4 & At1g43895 & unknown protein & 4.2 & 4.5 & 4.5 \\
\hline 27.3.99 & At2g26135 & zinc finger protein & 4.6 & 4.0 & 4.6 \\
\hline 10.8.1 & At1g69940 & PPME1 (pectinmethylesterase) & 4.3 & 4.1 & 4.5 \\
\hline 26.8 & At1g01980 & reticuline oxidase-like protein & 4.2 & 4.3 & 4.3 \\
\hline 35.2 & At4g25990 & CIL (chloroplast import apparatus 2-like protein) & 4.4 & 4.4 & 3.8 \\
\hline 35.1.12 & At5g56510 & APUM12 (Arabidopsis PUMILIO 12) & 3.0 & 5.0 & 4.6 \\
\hline 35.2 & At3g43572 & unknown protein & 5.9 & 2.4 & 4.1 \\
\hline 35.2 & At3g59620 & unknown protein & 3.6 & 4.4 & 4.6 \\
\hline 21.1 & At2g33270 & ACHT3 (atypical cysteine/histidine-rich thioredoxin 3) & 4.7 & 3.6 & 4.0 \\
\hline 20.1 .7 & At3g48231 & LCR48 (low-molecular-weight cysteine-rich protein 48) & 3.9 & 4.1 & 4.2 \\
\hline 35.2 & At3g50376 & unknown protein & 4.1 & 4.2 & 3.9 \\
\hline 35.2 & At1g55221 & unknown protein & 4.6 & 3.6 & 3.3 \\
\hline 31.4 & At1g07725 & ATEXO70H6 (exocyst subunit EXO70 family protein H6) & 3.7 & 3.9 & 3.5 \\
\hline 35.2 & At2g17305 & unknown protein & 3.8 & 3.9 & 3.4 \\
\hline 35.2 & At4g29200 & beta-galactosidase & 3.5 & 3.8 & 3.9 \\
\hline 33.99 & At5g07930 & MCT2 (mei2 C-terminal RRM only like 2 protein) & 4.2 & 2.8 & 4.2 \\
\hline 35.2 & At5g45690 & unknown protein & 4.0 & 4.2 & 2.9 \\
\hline 35.1 & At4g33820 & glycosyl hydrolase family 10 protein & 4.2 & 4.4 & 2.5 \\
\hline 27.3 .24 & At5g51860 & AGL72 (MADS-box protein) & 3.9 & 4.0 & 3.2 \\
\hline 27.3.7 & At3g21880 & zinc finger (B-box type) protein & 3.5 & 3.7 & 3.8 \\
\hline
\end{tabular}


Table 1 Genes which are regulated more than 4-fold (log2 value $\geq 2)$ in response to Pi limitation, P. indica and mutation of WRKY6 (Continued)

\begin{tabular}{|c|c|c|c|c|c|}
\hline 35.2 & At1g24256 & unknown protein & 2.4 & 3.9 & 4.6 \\
\hline 35.2 & At5g28295 & unknown protein & 3.6 & 3.4 & 3.5 \\
\hline 35.1 & At3g57840 & self-incompatibility protein-related protein & 3.1 & 3.7 & 3.6 \\
\hline 20.1 & At2g15040 & ATRLP18 (receptor-like protein 18) & 4.4 & 2.2 & 3.7 \\
\hline 29.5.11.4.3.2 & At5g53840 & FBL13 (F-box family protein 13) & 3.4 & 3.4 & 3.4 \\
\hline 35.2 & At2g11440 & unknown protein & 3.6 & 3.6 & 3.0 \\
\hline 35.1 & At3g48620 & unknown protein & 3.7 & 2.7 & 3.7 \\
\hline 29.3.4.1 & At2g38960 & AERO2 (Arabidopsis endoplasmic reticulum oxidoreductins 2) & 4.0 & 2.3 & 3.4 \\
\hline 35.1 & At4g26860 & pyridoxal phosphate binding protein & 3.7 & 2.9 & 3.1 \\
\hline 29.5.11.4.3.2 & At5g44220 & F-box family protein & 3.7 & 2.3 & 3.7 \\
\hline 20.1.7 & At4g09984 & LCR34 (low-molecular-weight cysteine-rich protein 34) & 3.2 & 3.3 & 3.2 \\
\hline 27.1 & At5g03580 & Putative polyadenylate-binding protein & 3.4 & 3.4 & 2.9 \\
\hline 35.2 & At4g08022 & unknown protein & 3.4 & 3.4 & 2.8 \\
\hline 35.2 & At4g05018 & unknown protein & 3.7 & 3.1 & 2.7 \\
\hline 33.99 & At1g21890 & nodulin MtN21 family protein & 2.9 & 3.1 & 3.5 \\
\hline 35.2 & At1g23910 & unknown protein & 3.0 & 3.6 & 2.9 \\
\hline 24 & At5g16080 & CXE17 (carboxyesterase 17) & 3.5 & 2.9 & 3.0 \\
\hline 35.2 & At5g51090 & unknown protein & 3.3 & 2.9 & 3.2 \\
\hline 33.99 & At2g30300 & nodulin-related protein & 3.2 & 3.0 & 3.0 \\
\hline 33.99 & At2g37860 & LCD1 (LOWER CELL DENSITY 1) & 3.0 & 3.3 & 2.9 \\
\hline 26.4.1 & At3g24330 & glycosyl hydrolase 17 & 2.9 & 3.0 & 3.1 \\
\hline 35.1 & At3g48209 & thionin family protein & 3.0 & 3.0 & 2.8 \\
\hline 20.1.7.12 & At4g14272 & defensin-like protein & 3.1 & 2.9 & 2.7 \\
\hline 10.8 .1 & At1g11590 & putative pectin methylesterase & 2.9 & 2.9 & 2.8 \\
\hline 29.5.11.1 & At5g48700 & ubiquitin-related protein & 2.5 & 3.4 & 2.6 \\
\hline 35.2 & At3g30520 & unknown protein & 2.8 & 2.8 & 2.8 \\
\hline 11.1.8 & At1g21540 & AMP-dependent synthetase and ligase family protein & 3.0 & 2.7 & 2.4 \\
\hline 35.2 & At3g43829 & unknown protein & 4.0 & 2.1 & 2.0 \\
\hline 35.2 & At5g29044 & unknown protein & 3.8 & 2.2 & 2.1 \\
\hline 35.1 & At3g58290 & meprin and TRAF homology domain-containing protein & 2.7 & 3.0 & 2.4 \\
\hline 35.2 & At1g57906 & unknown protein & 2.7 & 2.6 & 2.8 \\
\hline 26.3.2 & At4g38590 & glycosyl hydrolase 35 & 2.9 & 2.4 & 2.5 \\
\hline 30.2 .9 & At1g24650 & leucine-rich repeat family protein & 2.3 & 2.6 & 2.9 \\
\hline 27.3.24 & At2g24840 & AGL61 (AGAMOUS-LIKE 61) & 2.6 & 2.8 & 2.3 \\
\hline 35.1 .41 & At1g30795 & hydroxyproline-rich glycoprotein family protein & 2.9 & 2.4 & 2.3 \\
\hline 29.5 .7 & At3g59990 & MAP2B (METHIONINE AMINOPEPTIDASE 2B) & 2.6 & 2.4 & 2.7 \\
\hline 16.2 & At1g32910 & transferase & 2.8 & 2.0 & 2.6 \\
\hline 27.3.67 & At1g61320 & unknown protein & 2.4 & 2.2 & 2.8 \\
\hline 35.2 & At5g50360 & unknown protein & 2.1 & 2.5 & 2.8 \\
\hline 35.2 & At1g03240 & unknown protein & 2.5 & 2.5 & 2.3 \\
\hline 35.1 & At4g19910 & Toll-Interleukin-Resistance (TIR) domain-containing protein & 2.8 & 2.3 & 2.2 \\
\hline 35.1 & At3g06880 & nucleotide binding protein & 3.0 & 2.1 & 2.2 \\
\hline 35.1 & At5g52690 & heavy-metal-associated domain-containing protein & 2.4 & 2.4 & 2.2 \\
\hline 26.10 & At1g19630 & CYP722A1 (monooxygenase) & 2.5 & 2.5 & 2.0 \\
\hline
\end{tabular}


Table 1 Genes which are regulated more than 4-fold (log2 value $\geq 2$ ) in response to Pi limitation, P. indica and mutation of WRKY6 (Continued)

\begin{tabular}{lllrr}
\hline 35.2 & At3g58300 & unknown protein & 2.3 & 2.3 \\
35.2 & At3g43950 & phosphotransferase & 2.2 & 2.3 \\
35.2 & At1g53285 & unknown protein & 2.3 & 2.1 \\
35.2 & At4g20520 & RNA binding/RNA-directed DNA polymerase & -2.5 & 1.3 \\
17.1 .1 & At2g36020 & HVA22J (HVA22-LIKE PROTEIN J) & -2.3 & -2.5 \\
\hline
\end{tabular}

Table 1 and Additional file 2: Table S2 propose genes for quite diverse functions, but they may highlight those cellular and molecular processes which need to be activated to promote root growth and development. Interestingly, a literature and database survey uncovered that for the majority of the gene products, very limited or no information is available for their role in root growth regulation. Among the strongest upregulated genes is the well-studied SNF7, which codes for an interacting protein of the endosomal sorting complex required for transport (ESCRT)-III subunits. It regulates the formation of intraluminal vesicles of the prevacuolar compartments [54]. Another strongly regulated gene is SWEET5, a member of the sucrose phloem transporter family [51]. The specific role of SWEET5 in this scenario is unknown. Furthermore, it is interesting to note that only specific members of multigene families or a gene for one particular protein of a multiprotein complex respond to all three stimuli. The list of genes uncovered metabolic and signaling pathways which are limiting for root growth promotion. It is reasonable to assume that specific combinations of these genes/gene products are important, which can now be tested experimentally.

\section{Conclusion}

We conclude that three unrelated factors "presence of $P$. indica", "limitation of Pi" and "absence of WRKY6" influence $A$. thaliana growth and in particular the root architecture and propose that common genes which respond to all three growth stimuli are central for the control of root growth and architecture. These genes can be tested for optimizing root growth in model and agricultural plants.

\section{Methods}

\section{Growth conditions of plant and fungus}

Arabidopsis thaliana WT and wrky6 seeds were surface sterilized and placed on Petri dishes containing MS [90] nutrient medium. After cold treatment for $48 \mathrm{~h}$ at $4{ }^{\circ} \mathrm{C}$, the plates were incubated for 10 days at $22{ }^{\circ} \mathrm{C}$ under continuous illumination $\left(100 \mu \mathrm{mol} \mathrm{m} \mathrm{m}^{-2} \mathrm{~s}^{-1}\right)$. P. indica was cultured as described previously on Aspergillus minimal medium [91].

\section{Generation of the homozygous wrky6 lines}

Homozygocity of the SALK_012997 (N661529; European Arabidopsis Stock Centre) line was confirmed by PCR using a combination of a T-DNA left border primer and a gene-specific WRKY6 right border primer (Additional file 1: Table S1). Two different T-DNA left border primers, LBa1 (TGGTTCACGTAGTGGGCCATCG) and LBa1.3 (ATTTTGCCGATTTCGGAAC) were used. An additional PCR was performed to identify homozygous seedlings for the insertions using the gene-specific primers LP and RP (Additional file 2: Table S3).

\section{Co-cultivation experiments}

Co-cultivation of $A$. thaliana (WT and wrky6) with the fungus $P$. indica was performed under in vitro culture conditions on a nylon membrane placed on top of solified PNM media [91]. Square Petri dishes were divided into two equal parts and one $P$. indica disk was placed on each part and was grown for 10 days. After $48 \mathrm{~h}$ of cold treatment and 10 days of growth as described above, seedlings of equal sizes were used for the cocultivation assays. For Pi stress treatment PNM media with two different Pi concentrations [2.5 $\mathrm{mM}$ (normal $\mathrm{Pi}$ - NP) and $0.25 \mathrm{mM}$ (low Pi - LP)] were used. For each $\mathrm{Pi}$ concentration, 4 treatments were compared: $\mathrm{WT}, \mathrm{WT}+P$. indica, wrky6 and $w r k y 6+P$. indica. Seedlings were maintained under two different Pi concentrations as mentioned above for $3,5,6,12$ or 14 days at $22{ }^{\circ} \mathrm{C}$ and 70-80\% humidity in a 16-h light/8-h dark cycle. Roots and shoots were harvested separately and frozen in liquid nitrogen for further analyses. Only roots were used for gene expression analyses. Kaefer media (KM) disks were used for mock treatment. Mock-treated seedlings grown on $2.5 \mathrm{mM}$ NP were used as control.

\section{Experiments on expanded clay}

After co-cultivation with $P$. indica or mock treatment for 14 days on PNM plates, seedlings were transferred to Magenta boxes containing autoclaved expanded clay (one plant per box). Seedlings were supplied with $30 \mathrm{ml}$ liquid PNM media containing the two different Pi concentrations, once a week. Plants were grown in a temperature $\left(22{ }^{\circ} \mathrm{C}\right)$ and moisture-controlled room with light from the top $\left(80 \pm 10 \mu \mathrm{mol} \mathrm{m} \mathrm{m}^{-2} \mathrm{~s}^{-1}\right)$ under short-day conditions (8 $\mathrm{h}$ light and $16 \mathrm{~h}$ darkness). The light intensity was 
monitored weekly. The sizes of the seedlings were also monitored weekly and quantified after photography.

\section{Quantitative Real-Time-PCR}

RNA was isolated from root tissues after 3 days post incubation (dpi) as described by Sun et al. [92]. All reactions were performed from three biological and three technical replicates. The mRNA levels for each cDNA probe were normalized with respect to the plant glyceraldehyde-3-Pi dehydrogenase (GAPDH) mRNA levels, which has been validated as a reference gene for roots inoculated with $P$. indica ([92], and references therein). Fold-induction values of target genes were calculated with the $\triangle \triangle C P$ equation of Pfaffl [93] and related to the mRNA level of target genes for mocktreated roots from NP, which were defined as 1.0. Primer pairs used in this study are given in Additional file 2: Table S3.

\section{Root colonization}

Roots from plates were harvested after 14 dpi of cocultivation and were washed intensively with distilled water before RNA extraction. $P$. indica was monitored with a primer pair for the ELONGATION FACTOR1 $(P i E F-H)$ mRNA. The mRNA levels for PiEF-H were normalized with respect to the plant GAPDH mRNA levels. Staining of hyphae and spores was performed with Trypan blue $(0.05 \%)$ prior to light microscopy [91].

\section{Pi content analysis}

Seedlings were grown under the two different Pi conditions for $12 \mathrm{dpi}$ as described above. Shoots and roots were sampled separately. Fresh mass were measured, before the samples were dried in an oven at $105{ }^{\circ} \mathrm{C}$ overnight. For Pi content analyses, samples were mixed with $2 \mathrm{ml}$ of $65 \% \mathrm{HNO}_{3}$ and kept for one hour at $160{ }^{\circ} \mathrm{C}$. The final volume was adjusted to $10 \mathrm{ml}$ and the $\mathrm{pH}$ to 3.0-4.0. Finally, samples were mixed with ascorbic acid reagent and ammonium molybdate reagent (DIN 38405) and the Pi content was analyzed by the phosphomolybdenum blue reaction using the UV-160A spectrophotometer. Total Pi concentration was expressed in $\mu \mathrm{mol} / \mathrm{g}$ dry weight. Experiments were repeated 3 times with independent material.

\section{${ }^{32} \mathrm{P}$ uptake assay}

WT and wrky6 mutant were co-cultivated with/without $P$. indica on PNM media with two different Pi concentrations as described above for 5 days. After $5 \mathrm{dpi}$, $2.5 \mu \mathrm{Ci}$ or $25 \mathrm{nM}$ of ${ }^{32} \mathrm{P}$-ortho-Pi were added to each plant (1 plant per plate), and the seedlings were again allowed to grow for 3 days. Roots and shoots were harvested separately and washed several times in Na-citrate buffer (10 mM, pH 6.0). Roots and shoots were dried in an oven at $70{ }^{\circ} \mathrm{C}$, weighted and digested with a tissue solubilizer (Rotiszint ${ }^{\oplus}$-eco plus). The radioactivity was determined by liquid scintillation counting (LS 6500) using standard full channel programs in single isotope experiments.

\section{Determination of root hair density, length and primary root length}

Arabidopsis seedlings were grown on square Petri dishes and kept vertically. Co-cultivation with $P$. indica was performed as described above with a few modifications: (a) for PNM media gelrite was used instead of agar, (b) no membranes were used to enhance the visibility of the roots. After $14 \mathrm{dpi}$ the images of roots were taken under a stereomicroscope (Leica MZ6) and the digital images were traced by hand using Image $1.47 \mathrm{v}(\mathrm{NIH})$. Finally the pixels were converted into the appropriate metric equivalents. For the determinations of primary root lengths, seedlings were grown on liquid medium with $P$. indica spores under the different $\mathrm{Pi}$ conditions for 14 days, stained with trypan blue for $5 \mathrm{~min}$ and then placed on glass slides. Pictures of seedlings were scanned using a Desktop scanner at $600 \mathrm{dpi}$. These scanned pictures were further analyzed using ImageJ $1.47 \mathrm{v}(\mathrm{NIH})$.

\section{Microarray analyses}

Total RNA from roots of colonized WT and wrky6 mutants from 3 independent biological experiments grown under NP and LP conditions were harvested at $3 \mathrm{dpi}$. RNA from roots of mock-treated WT and wrky6 mutants were used as control. For each treatment, same amounts of RNA from three independent biological replicates were labeled and hybridized according to Agilent's One-Color Microarray-Based Gene Expression Analysis (OAK Lab GmBH, Hennigdorf, Germany). Quality of RNA samples were checked by photometrical measurements with the Nanodrop 2000 spectrophotometer (Thermo Scientific) and then analyzed on agarose gels (2\%) as well as by using the 2100 Bioanalyser (Agilent Technologies, CA) for determining the RNA integrity and the exclusion of potential contaminants. After verifying the quality of RNA, the Low Input Quick Amp Labeling Kit (Agilent Technologies) was used for generation of fluorescent complementary RNA (cRNA). Default cRNAs were amplified by using oligo-dT primers labeled with cyanine 3-CTP (Cye-3) according to the manufacturer's protocol. Cye-3-labeled probes were hybridized to $8 \times 60 \mathrm{k}$ custom-designed Agilent microarray chips. For hybridization the Gene Expression Hybridization Kit (Agilent Technologies) was used. The hybridized slides were washed and scanned using the SureScan Microarray Scanner (Agilent Technologies) at a resolution of $3 \mu \mathrm{m}$ generating a 20 bit TIFF file, respectively. 


\section{Microarray data analysis}

Data extractions from Images were performed using the Agilent's Feature Extraction software version 11. Feature extracted data were analyzed using the DirectArray Version 2.1 software from Agilent. Normalization of the data was performed with DirectArray using the ranked median quantiles according to Bolstad et al. [94]. To identify significantly differentially expressed genes $\log _{2}$-fold changes are calculated and Student's $t$ test was performed. In summary, raw data were normalized by rank median quantiles, intensity values from replicate probes were averaged, $\log _{2}$-ratios between the treatments were calculated and Student's $t$-statistics applied to test for significance. Genes with $\log _{2}$-fold change $<-1$ or $>1$ and $p$-value $<0.05$ were considered to be significantly different. Genes were classified based on functional categories and pathways using the MapMan (http://mapman.gabipd.org/web/guest/ mapman) and $A$. thaliana Gene Ontology softwares (TAIR's GO annotations) [95].

Microarray data were verified by qRT-PCR as described previously from three independent biological experiments with three technical replicates (Additional file 2: Table S4). The microarray data have been submitted to NCBI (GEO) under the accession number GSE63500 (https://www.ncbi.nlm.nih.gov/geo/query/ acc.cgi? acc $=$ GSE63500).

\section{Quantification of ET}

For ET measurements, $100 \mathrm{mg}$ shoot material from each treatment was collected into $4 \mathrm{ml}$ vials (Roth, Germany). After $3 \mathrm{~h}$ ET accumulation, the measurement was performed with the ETD-300 ET detector (Sensor Sense B.V., Nijmegen, The Netherlands) as described in Bhattacharya and Baldwin [96] and Sun et al. [92].

\section{Statistical analyses}

The statistical analyses for the microarray data have been described above. All additional statistical analyses were performed using Excel (2010) for Student's paired $t$-test for two tailed distribution.

\section{Availability of supporting data}

The data sets supporting the results of this article are included within the article and its additional files. The microarray data have been submitted to NCBI (GEO) under the accession number GSE63500.

\section{Additional files}

Additional file 1: Table S1. Genes which are up-regulated more than 2 -fold in $w r k y 6+P$. indica in LP ( $\log _{2}$ value $\geq 1$ or $\left.\leq-1\right)$. (XLS $200 \mathrm{~kb}$ )

Additional file 2: Table S2. Genes which were regulated more than 2 -fold ( $\log 2$ value $\geq 1$ ) in response to Pi limitation, $P$. indica and mutation of WRKY6. Table S3. Primers used in this study. Table S4. Microarray validation with Real-time PCR. (PDF 563 kb)

\section{Abbreviations}

Pi: Piriformospora indica; P: phosphorus; Pi: phosphate; AM: arbuscular mycorrhiza; TFs: transcription factors; PHO1: phosphate1; NP: normal phosphate; LP: low phosphate; dpi: days post incubation; ET: ethylene; WT: wild-type.

\section{Competing interests}

The authors declare that they have no competing interests.

\section{Authors' contributions}

$M B$ designed and carried out all experiments and wrote the article. KV helped in the microarray analysis. SB did the phytohormone analysis. IS, AV, K-WY, ITB and AKJ contributed to the discussion. RO designed the experiments, wrote the article and supervised the research. All authors read and approved the final manuscript.

\section{Acknowledgements}

MB was supported by the Deutscher Akademischer Austauschdienst (DAAD). This work was supported by the Collaborative Research Center 1127 (Deutsche Forschungsgemeinschaft, Project A03), the International Max-Planck Research School Jena and the Jena School of Microbial Communication. RO and KWY were supported by a travel grant from the DAAD.

\section{Author details}

${ }^{1}$ Institute of General Botany and Plant Physiology, Friedrich-Schiller-University Jena, Dornburgerstr. 159, D-07743 Jena, Germany. ${ }^{2}$ Max-Planck-Institute for Chemical Ecology, Beutenberg Campus, Hans-Knöll-Straße 8, D-07745 Jena, Germany. ${ }^{3}$ Amity Institute of Microbial Technology, AUUP, Noida, India. ${ }^{4}$ Institute of Plant Biology, Taiwan National University, Taipei, Taiwan. ${ }^{5}$ School of Life Sciences, Jawaharlal Nehru University, New Delhi 110067, India.

Received: 1 August 2015 Accepted: 3 December 2015

Published online: 30 December 2015

\section{References}

1. Liang C, Wang J, Zhao J, Tian J, Liao H. Control of phosphate homeostasis through gene regulation in crops. Curr Opin Plant Biol. 2014;21:59-66.

2. Fusconi A. Regulation of root morphogenesis in arbuscular mycorrhizae: what role do fungal exudates, phosphate, sugars and hormones play in lateral root formation? Ann Bot. 2014;113:19-33.

3. Péret B, Clément M, Nussaume L, Desnos T. Root developmental adaptation to phosphate starvation: better safe than sorry. Trends Plant Sci. 2011;16: 442-50.

4. Niu YF, Chai RS, Jin GL, Wang H, Tang CX, Zhang YS. Responses of root architecture development to low phosphorus availability: a review. Ann Bot. 2013;112:391-408

5. Doerner P. Phosphate starvation signaling: a threesome controls systemic P(i) homeostasis. Curr Opin Plant Biol. 2008;11:536-40.

6. Batjes NH. A world data set for derived soil properties by FAO-UNESCO soil unit for global modelling. Soil Use Manage. 1997;13:9-16.

7. Downing JA, Watson SB, McCauley E. Predicting cyanobacterial dominance in lakes. Can J Fish Aquat Sci. 2001;58:1905-8.

8. Hu B, Zhu C, Li F, Tang J, Wang Y, Lin A, et al. LEAF TIP NECROSIS1 plays a pivotal role in the regulation of multiple phosphate starvation responses in rice. Plant Physiol. 2011;156:1101-15.

9. Lambers H, Finnegan PM, Laliberte E, Pearse SJ, Ryan MH, Shane MW, et al. Phosphorus nutrition of proteaceae in severely phosphorus-impoverished soils: Are there lessons to be learned for future crops? Plant Physiol. 2011; 156:1058-66.

10. Vance CP, Uhde-Stone C, Allan DL. Phosphorus acquisition and use: critical adaptations by plants for securing a nonrenewable resource. New Phytol. 2003;157:423-47.

11. Lambers H, Shane MW, Cramer MD, Pearse SJ, Veneklaas EJ. Root structure and functioning for efficient acquisition of phosphorus: matching morphological and physiological traits. Ann Bot. 2006;98:693-713.

12. Yang SY, Paszkowski U. Phosphate import at the arbuscule: just a nutrient? Mol Plant-Microbe Interact. 2011;24:1296-9. 
13. Balzergue $C$, Puech-Pagès $V$, Bécard $G$, Rochange SF. The regulation of arbuscular mycorrhizal symbiosis by phosphate in pea involves early and systemic signalling events. J Exp Bot. 2011;62:1049-60.

14. Camehl I, Drzewiecki C, Vadassery J, Shahollari B, Sherameti I, Forzani C, et al. The OXI1 kinase pathway mediates Piriformospora indica-induced growth promotion in Arabidopsis. PLoS Pathog. 2011;7, e1002051.

15. Jogawat A, Saha S, Bakshi M, Dayaman V, Kumar M, Dua M, et al. Piriformospora indica rescues growth diminution of rice seedlings during high salt stress. Plant Signal Behav. 2013;8, e26891.

16. Ye W, Shen $\mathrm{CH}$, Lin $Y$, Chen PJ, Xu X, Oelmüller R, et al. Growth promotionrelated miRNAs in Oncidium orchid roots colonized by the endophytic fungus Piriformospora indica. PLoS One. 2014;9, e84920.

17. Sherameti I, Shahollari B, Venus Y, Altschmied L, Varma A, Oelmüller R. The endophytic fungus Piriformospora indica stimulates the expression of nitrate reductase and the starch-degrading enzyme glucan-water dikinase in tobacco and Arabidopsis roots through a homeodomain transcription factor that binds to a conserved motif in their promoters. J Biol Chem. 2005:280: 26241-7.

18. Kumar M, Yadav V, Kumar H, Sharma R, Singh A, Tuteja N, et al. Piriformospora indica enhances plant growth by transferring phosphate. Plant Signal Behav. 2011;6:723-5.

19. Yadav V, Kumar M, Deep DK, Kumar H, Sharma R, Tripathi T, et al. A phosphate transporter from the root endophytic fungus Piriformospora indica plays a role in phosphate transport to the host plant. J Biol Chem. 2010;285:26532-44.

20. Pedersen BP, Kumar H, Waight AB, Risenmay AJ, Roe-Zurz Z, Chau BH, et al. Crystal structure of a eukaryotic phosphate transporter. Nature. 2013;496: 533-6.

21. Venus $Y$, Oelmüller R. Arabidopsis ROP1 and ROP6 influence germination time, root morphology, the formation of F-actin bundles, and symbiotic fungal interactions. Mol Plant. 2013;6:872-86

22. Vadassery J, Ranf S, Drzewiecki C, Mithofer A, Mazars C, Scheel D, et al. A cell wall extract from Piriformospora indica promotes growth of Arabidopsis seedlings and induces intracellular calcium elevation in roots. Plant J. 2009; 59:193-206.

23. Barazani O, Benderoth M, Groten K, Kuhlemeier C, Baldwin IT. Piriformospora indica and Sebacina vermifera increase growth performance at the expense of herbivore resistance in Nicotiana ttenuate. Oecologia. 2005;146:234-43.

24. Waller F, Achatz B, Baltruschat H, Fodor J, Becker K, Fischer M, et al. The endophytic fungus Piriformospora indica reprograms barley to salt-stress tolerance, disease resistance, and higher yield. Proc Natl Acad Sci U S A. 2005;102:13386-91.

25. Baltruschat H, Fodor J, Harrach BD, Niemczyk E, Barna B, Gullner G, et al. Salt tolerance of barley induced by the root endophyte Piriformospora indica is associated with a strong increase in antioxidants. New Phytol. 2008;180:501-10.

26. Pedrotti L, Mueller MJ, Waller F. Piriformospora indica root colonization triggers local and systemic root responses and inhibits secondary colonization of distal roots. PLoS One. 2013;8, e69352.

27. Fakhro A, Andrade-Linares DR, von Bargen S, Bandte M, Büttner C, Grosch R, et al. Impact of Piriformospora indica on tomato growth and on interaction with fungal and viral pathogens. Mycorrhiza. 2010;20:191-200.

28. Das A, Kamal S, Shakil NA, Sherameti I, Oelmüller R, Dua M, et al. The root endophyte fungus Piriformospora indica leads to early flowering, higher biomass and altered secondary metabolites of the medicinal plant Coleus forskohlii. Plant Signal Behav. 2012;7:103-12.

29. Sherameti I, Tripathi S, Varma A, Oelmüller R. The root-colonizing endophyte Pirifomospora indica confers drought tolerance in Arabidopsis by stimulating the expression of drought stress-related genes in leaves. Mol Plant-Microbe Interact. 2008;21:799-807

30. Khatabi B, Schäfer P. Ethylene in mutualistic symbioses. Plant Signal Behav. 2012;7:1634-8.

31. Chi Y, Yang Y, Zhou Y, Zhou J, Fan B, Yu JQ, et al. Protein-protein interactions in the regulation of WRKY transcription factors. Mol Plant. 2013;6:287-300.

32. Bakshi M, Oelmüller R. WRKY transcription factors: Jack of many trades in plants. Plant Signal Behav. 2014;9, e27700.

33. Llorca CM, Potschin M, Zentgraf U. bZIPs and WRKYs: two large transcription factor families executing two different functional strategies. Front Plant Sci. 2014;5:169.

34. Chen YF, Li LQ, Xu Q, Kong YH, Wang H, Wu WH. The WRKY6 transcription factor modulates PHOSPHATE1 expression in response to low Pi stress in Arabidopsis. Plant Cell. 2009;21:3554-66.
35. Devaiah BN, Karthikeyan AS, Raghothama KG. WRKY75 transcription factor is a modulator of phosphate acquisition and root development in Arabidopsis. Plant Physiol. 2007;143:1789-90.

36. Devaiah BN, Raghothama KG. Transcriptional regulation of Pi starvation responses by WRKY75. Plant Signal Behav. 2007;2:424-5.

37. Ma Z, Baskin Tl, Brown KM, Lynch JP. Regulation of root elongation under phosphorus stress involves changes in ethylene responsiveness. Plant Physiol. 2003;131:1381-90.

38. Ishii T, Shrestha YH, Matsumoto I, Kadoya K. Effect of ethylene on the growth of vesicular-arbuscular mycorrhizal fungi and on the mvcorrhizal formation of trifoliate orange roots. J J.pn Soc Hortic Sci. 1996;65:525-9.

39. Hamburger D, Rezzonico E, Petétot JMC, Somerville C, Poirier Y. Identification and characterization of the Arabidopsis $\mathrm{PHO} 1$ gene involved in phosphate loading to the xylem. Plant Cell. 2002;14:889-902.

40. Krogan NT, Yin X, Ckurshumova W, Berleth T. Distinct subclades of AuX/IAA genes are direct targets of ARF5/MP transcriptional regulation. New Phytol. 2014;204:474-83.

41. Guilfoyle TJ, Hagen G. Getting a grasp on domain III/IV responsible for Auxin Response Factor-IAA protein interactions. Plant Sci. 2012; 190:82-8

42. Benschop JJ, Millenaar FF, Smeets ME, van Zanten M, Voesenek LA, Peeters AJ. Abscisic acid antagonizes ethylene-induced hyponastic growth in Arabidopsis. Plant Physiol. 2007;143:1013-23.

43. Chen CN, Chu CC, Zentella R, Pan SM, Ho THD. AtHVA22 gene family in Arabidopsis: phylogenetic relationship, $\mathrm{ABA}$ and stress regulation, and tissue-specific expression. Plant Mol Biol. 2002;49:631-42.

44. Yang F, Song Y, Yang H, Liu Z, Zhu G, Yang Y. An auxin-responsive endogenous peptide regulates root development in Arabidopsis. J Integr Plant Biol. 2014;56:635-47.

45. Löhr B, Streitner C, Steffen A, Lange T, Staiger D. A glycine-rich RNA-binding protein affects gibberellin biosynthesis in Arabidopsis. Mol Biol Rep. 2014;41: 439-45.

46. Hsieh LC, Lin SI, Shih AC, Chen JW, Lin WY, Tseng CY, et al. Uncovering small RNA-mediated responses to phosphate deficiency in Arabidopsis by deep sequencing. Plant Physiol. 2009;151:2120-32.

47. Pant BD, Musialak-Lange M, Nuc P, May P, Buhtz A, Kehr J, et al Identification of nutrient-responsive Arabidopsis and rapeseed microRNAs by comprehensive real-time polymerase chain reaction profiling and small RNA sequencing. Plant Physiol. 2009;150:1541-55.

48. Song JB, Huang SQ, Dalmay T, Yang ZM. Regulation of leaf morphology by microRNA394 and its target leaf curling responsiveness. Plant Cell Physiol. 2012;53:1283-94.

49. Sorin C, Marie D, Aurélie C, Thomas B, Linnan M, Christine L-B, et al. A miR169 isoform regulates specific NF-YA targets and root architecture in Arabidopsis. New Phytol. 2014;202:1197-11.

50. He H, Liang G, Li Y, Wang F, Yu D. Two young microRNAs originating from target duplication mediate nitrogen starvation adaptation via regulation of glucosinolate synthesis in Arabidopsis thaliana. Plant Physiol. 2014;164:853-65.

51. Chen LQ, Qu XQ, Hou BH, Sosso D, Osorio S, Fernie AR, et al. Sucrose efflux mediated by SWEET proteins as a key step for phloem transport. Science. 2012;335:207-11

52. Goda H, Sawa S, Asami T, Fujioka S, Shimada Y, Yoshida S. Comprehensive comparison of auxin-regulated and brassinosteroid-regulated genes in Arabidopsis. Plant Physiol. 2004:134:1555-73.

53. Kiba T, Naitou T, Koizumi N, Yamashino T, Sakakibara H, Mizuno T. Combinatorial microarray analysis revealing Arabidopsis genes implicated in cytokinin responses through the His- > Asp Phosphorelay circuitry. Plant Cell Physiol. 2005;466:339-55.

54. Cai Y, Zhuang X, Gao C, Wang X, Jiang L. The Arabidopsis endosomal sorting complex required for transport III regulates internal vesicle formation of the prevacuolar compartment and is required for plant development. Plant Physiol. 2014;165:1328-43.

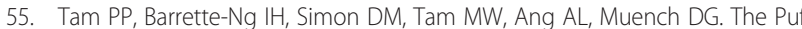
family of RNA-binding proteins in plants: phylogeny, structural modeling, activity and subcellular localization. BMC Plant Biol. 2010;10:44.

56. Zhang $H$, Kim MS, Krishnamachari $V$, Payton $P$, Sun $Y$, Grimson $M$, et al Rhizobacterial volatile emissions regulate auxin homeostasis and cell expansion in Arabidopsis. Planta. 2007;226:839-51. 
57. Müller R, Morant M, Jarmer H, Nilsson L, Nielsen TH. Genome-wide analysis of the Arabidopsis leaf transcriptome reveals interaction of phosphate and sugar metabolism. Plant Physiol. 2007;143:156-71.

58. Robatzek S, Somssich IE. Targets of AtWRKY 6 regulation during plant senescence and pathogen defense. Genes Dev. 2002;16:1139-49.

59. Sukumar $P$, Legué $V$, Vayssières A, Martin F, Tuskan GA, Kalluri UC. Involvement of auxin pathways in modulating root architecture during beneficial plantmicroorganism interactions. Plant Cell Environ. 2013:36:909-19.

60. Mukherjee K, Ane J. Germinating spore exudates from arbuscular mycorrhizal fungi: molecular and developmental responses in plants and their regulation by ethylene. Mol Plant-Microbe Interact. 2011;24:260-70.

61. López-Arredondo DL, Leyva-Gonzalez MA, Gonzalez-Morales SI, López-Bucio J, Herrera-Estrella L. Phosphate nutrition: Improving low-phosphate tolerance in crops. Ann Rev Plant Biol. 2014;65:95-123.

62. Dong S, Tian Z, Chen PJ, Senthil KR, Shen CH, Cai D, et al. The maturation zone is an important target of Piriformospora indica in Chinese cabbage roots. J Exp Bot. 2013;64:4529-40.

63. Lee YC, Johnson JM, Chien CT, Sun C, Cai D, Lou B, et al. Growth promotion of Chinese cabbage and Arabidopsis by Piriformospora indica is not stimulated by mycelium-synthesized auxin. Mol Plant-Microbe Interact. 2011;24:421-31.

64. Glassop D, Godwin RM, Smith SE, Smith FW. Rice phosphate transporters associated with phosphate uptake in rice roots colonized with arbuscular mycorrhizal fungi. Botany. 2007;85:644-51.

65. Harrison MJ, Dewbre GR, Liu J. A phosphate transporter from Medicago truncatula involved in the acquisition of phosphate released by arbuscular mycorrhizal fungi. Plant Cell. 2002;14:2413-29.

66. Shahollari B, Varma A, Oelmüller R. Expression of a receptor kinase in Arabidopsis roots is stimulated by the basidiomycete Piriformospora indica and the protein accumulates in Triton X-100 insoluble plasma membrane microdomains. J Plant Physiol. 2005;162:945-58.

67. Rausch C, Bucher M. Molecular mechanisms of phosphate transport in plants. Planta. 2002;216:23-37.

68. Schachtman DP, Reid RJ, Ayling SM. Phosphorus uptake by plants: From soil to cell. Plant Physiol. 1998;116:447-53.

69. Javot H, Pumplin N, Harrison MJ. Phosphate in the arbuscular mycorrhizal symbiosis: transport properties and regulatory roles. Plant Cell Environ. 2007; 30:310-22.

70. Ai P, Sun S, Zhao J, Fan X, Xin W, Guo Q, et al. Two rice phosphate transporters, OsPht1;2 and OsPht1;6, have different functions and kinetic properties in uptake and translocation. Plant J. 2009;57:0798-809.

71. Lynch J, Brown KM. Ethylene and plant responses to nutritional stress. Physiol Plant. 1997;100:613-9.

72. Camehl I, Sherameti I, Venus Y, Bethke G, Varma A, Lee J, et al. Ethylene signalling and ethylene-targeted transcription factors are required to balance beneficial and nonbeneficial traits in the symbiosis between the endophytic fungus Piriformospora indica and Arabidopsis thaliana. New Phytol. 2010;185:1062-73.

73. Peškan-Berghöfer T, Shahollari B, Giong PH, Hehl S, Markert C, Blanke V, et al. Association of Piriformospora indica with Arabidopsis thaliana roots represents a novel system to study beneficial plant-microbe interactions and involves early plant protein modifications in the endoplasmic reticulum and at the plasma membrane. Physiol Plantarum. 2004;122:465-77.

74. Oelmüller R, Peškan-Berghöfer $T$, Shahollari B, Trebicka A, Sherameti I, Varma A. MATH domain proteins represent a novel protein family in Arabidopsis thaliana, and at least one member is modified in roots during the course of a plant-microbe interaction. Physiol Plantarum. 2005;124:152-66.

75. Vadassery J, Ritter C, Venus Y, Camehl I, Varma A, Shahollari B, et al. The role of auxins and cytokinins in the mutualistic interaction between Arabidopsis and Piriformospora indica. Mol Plant-Microbe Interact. 2008:21:1371-83.

76. Spartz AK, Lee SH, Wenger JP, Gonzalez N, Itoh H, Inzé D, et al. The SAUR19 subfamily of small auxin-up RNA genes promotes cell expansion. Plant J. 2012;70:978-90.

77. Wang SK, Zhang SN, Sun CD, Xu YX, Chen $Y, Y u C L$, et al. Auxin response factor (OsARF12), a novel regulator for phosphate homeostasis in rice (Oryza sativa). New Phytol. 2014;201:91-103.

78. Qi YH, Wang SK, Shen CJ, Zhang SN, Chen Y, Xu YX, et al. OsARF12, a transcription activator on auxin response gene, regulates root elongation and affects iron accumulation in rice (Oryza sativa). New Phytol. 2012:193: $109-20$
79. Bruex A, Kainkaryam RM, Wieckowski Y, Kang YH, Bernhardt C, Xia Y, et al. A gene regulatory network for root epidermis cell differentiation in Arabidopsis. PLoS Genet. 2012;8, e1002446.

80. Hur YS, Um JH, Kim S, Kim K, Park HJ, Lim JS, et al. Arabidopsis thaliand homeobox 12 (ATHB12), a homeodomain-leucine zipper protein, regulates leaf growth by promoting cell expansion and endoreduplication. New Phytol. 2014:205:316-28.

81. Bernal AJ, Yoo CM, Mutwil M, Jensen JK, Hou G, Blaukopf C, et al. Functional analysis of the cellulose synthase-like genes CSLD1, CSLD2, and CSLD4 in tip-growing Arabidopsis cells. Plant Physiol. 2008;148:1238-53.

82. Yang DL, Yao J, Mei CS, Tong XH, Zeng LJ, Li Q, et al. Plant hormone jasmonate prioritizes defense over growth by interfering with gibberellin signaling cascade. Proc Natl Acad Sci U S A. 2012;109:E1192-200.

83. Simon SA, Meyers BC, Sherrier DJ. MicroRNAs in the rhizobia legume symbiosis. Plant Physiol. 2009;151:1002-8.

84. Gu M, Xu K, Chen A, Zhu Y, Tang G, Xu G. Expression analysis suggests potential roles of microRNAs for phosphate and arbuscular mycorrhizal signaling in Solanum lycopersicum. Physiol Plantarum. 2010;138:226-37.

85. Gu M, Liu W, Meng Q, Zhang W, Chen A, Sun S, et al. Identification of microRNAs in six solanaceous plants and their potential link with phosphate and mycorrhizal signaling. J Integr Plant Biol. 2014;56:1164-78.

86. Hajdarpaši A, Ruggenthaler P. Analysis of miRNA expression under stress in Arabidopsis thaliana. Bosn J Basic Med Sci. 2012;12:169-76.

87. Sunkar R, Yong-Fang L, Guru J. Functions of microRNAs in plant stress responses. Trends Plant Sci. 2012;17:196-203.

88. Khan GA, Declerck M, Sorin C, Hartmann C, Crespi M, Lelandais BC MicroRNAs as regulators of root development and architecture. Plant Mol Biol. 2011;77:47-58.

89. Li C, Zhang B. MicroRNAs in Control of Plant Development. J Cell Physiol. 2016:231:303-13.

90. Murashige T, Skoog F. A revised medium for rapid growth and bioassays with tobacco tissue cultures. Physiol Plant. 1962;15:473-97.

91. Johnson JM, Sherameti I, Ludwig A, Nongbri PL, Sun C, Lou B, et al. Protocols for Arabidopsis thaliana and Piriformospora indica co-cultivation - A model system to study plant beneficial traits. J Endocyt Cell Res. 2011;101-13.

92. Sun C, Shao Y, Vahabi K, Lu J, Bhattacharya S, Dong S, et al. The beneficial fungus Piriformospora indica protects Arabidopsis from Verticillium dahliae infection by downregulation plant defense responses. BMC Plant Biol. 2014; 14:268.

93. Pfaffl MW. A new mathematical model for relative quantification in real-time RT-PCR. Nucleic Acids Res. 2001;29, e45.

94. Bolstad BM, Rafael Al, Magnus A, Terence PS. A comparison of normalization methods for high density oligonucleotide array data based on variance and bias. Bioinformatics. 2003;19:185-93.

95. Berardini TZ, Mundodi S, Reiser L, Huala E, Garcia-Hernandez M, Zhang P, et al. Functional annotation of the Arabidopsis genome using controlled vocabularies. Plant Physiol. 2004;135:745-55.

96. Bhattacharya S, Baldwin IT. The post-pollination ethylene burst and the continuation of floral advertisement are harbingers of non-random mate selection in Nicotiana attenuata. Plant J. 2012;71:587-601.

\section{Submit your next manuscript to BioMed Central and we will help you at every step:}

- We accept pre-submission inquiries

- Our selector tool helps you to find the most relevant journal

- We provide round the clock customer support

- Convenient online submission

- Thorough peer review

- Inclusion in PubMed and all major indexing services

- Maximum visibility for your research

Submit your manuscript at www.biomedcentral.com/submit 